\title{
Longitudinal Shear Resistance of Composite Slabs Containing Crumb Rubber in Concrete Toppings
}

\author{
Niall Holmes \\ Technological University Dublin, niall.holmes@tudublin.ie \\ Kevin Dunne \\ Technological University Dublin \\ John O'Donnell \\ Technological University Dublin
}

Follow this and additional works at: https://arrow.tudublin.ie/engschcivart

Part of the Civil Engineering Commons, and the Construction Engineering and Management Commons

\section{Recommended Citation}

Holmes, N., Dunne, K. \& O'Donnell, J. (2014) Longitudinal shear resistance of composite slabs containing crumb rubber in concrete toppings, Construction and Building Materials, Vol. 55, pp.365-378. doi:10.1016/ j.conbuildmat.2014.01.046

This Article is brought to you for free and open access by the School of Civil and Structural Engineering at ARROW@TU Dublin. It has been accepted for inclusion in Articles by an authorized administrator of ARROW@TU Dublin. For more information, please contact arrow.admin@tudublin.ie, aisling.coyne@tudublin.ie, gerard.connolly@tudublin.ie.

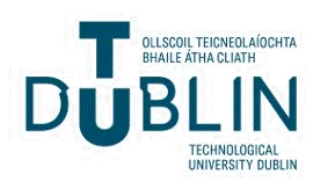




\section{LONGITUDINAL SHEAR RESISTANCE OF COMPOSITE SLABS CONTAINING CRUMB RUBBER IN CONCRETE TOPPINGS}

Niall Holmes*, Kevin Dunne and John O’Donnell

Dublin Institute of Technology,

Department of Civil and Structural Engineering,

Bolton Street,

Dublin 1,

Ireland.

Phone: +35314022914

Email: niall.holmes@dit.ie

*Corresponding Author 


\section{ABSTRACT}

This paper investigates the behaviour and longitudinal shear capacity of metal deck composite slabs with the inclusion of crumb rubber in the concrete toppings.

The ability of the slabs to act compositely is governed by the shear interaction between the concrete topping and the profiled steel deck. Results here show that crumb rubber concrete (CRC) improve the overall shear bond capacity between the steel deck and topping following an experimental study on full scale loading tests in accordance with Eurocode 4.

The results confirm that composite slabs incorporating crumb rubber had no effect on the longitudinal shear resistance with similar failure loads and behaviours to plain concrete. It also demonstrates a practical use for recycled tyres in the form of crumb rubber which are an environmental problem.

Keywords: $\quad$ crumb rubber concrete; composite slabs; profiled metal deck; longitudinal shear 


\section{INTRODUCTION}

Steel skeleton-framed buildings incorporating composite floors are a popular and economical form of construction due to their lightweight nature and speed of erection [Mullett, 2000]. Composite slabs consist of a profiled steel deck providing permanent formwork for in-situ construction. The steel deck provides the tensile reinforcement, which reduces the need for such in the concrete topping. Composite slabs span in the direction of the longitudinal ribs onto support beams at either end. A light reinforcement mesh (often referred to as anti-crack mesh reinforcement) is provided in the concrete topping as shown in Figure 1.

Previous work on the inclusion of crumb rubber in concrete (termed crumb rubber concrete, CRC) [Abdullah, 2004; Bravo and Brito, 2012; Fattuhi and Clark, 1996; Hedoo et al, 2012; Nehdi et al, 2001; Raghavan et al, 1998; Siddique et al, 2004] found an improvement in its capacity to absorb plastic energy under compression and tensile loading. It has also been shown to better withstand large deformations under loading [Li et al, 1998]. Structural applications of CRC have been limited due to the negative effect on the compressive load capacity so current work is focussed on applications where high compressive strength is not essential.

In order for composite systems to work effectively under vertical loading, profiled decks and concrete toppings must transfer longitudinal shear forces induced. Longitudinal shear failures occur when slip occurs between the steel deck and concrete prior to the plastic bending capacity of the slab is reached and an inadequate shear connection between the two materials exists. Longitudinal shear failure is manifested by diagonal shear cracks developing in close proximity to the point of loading which are followed by longitudinal slippage between the concrete and steel in the constant shear zone as shown in Figure 2.

The shear bond between the concrete and profiled steel deck can be separated into three components namely chemical bond (the chemical adherence of the cement paste to the profile steel deck), mechanical bond (the physical mechanical interlock between the concrete and profiled steel deck by shear studs or embossments on the steel) and frictional bond (created from the direct application of active normal forces which act perpendicular to the interface of the concrete and deck). 
This paper investigates the effect of recycled shredded car tyres in the form of crumb rubber in concrete toppings of metal decks on the longitudinal shear capacity of a number of composite slabs in bending. The results will demonstrate a practical application of an otherwise land-filled material while improving the environmental effect of composite slabs and reducing their unit weight.

\section{EXPERIMENTAL PROGRAMME}

2.1 Concrete mix constituents and proportions

Following a number of trial mixes, the mix constituents for the control ( $0 \%$ CRC) and CRC slabs with a $7.5 \%$ replacement level of fine aggregate are shown in Tables 1 and 2 respectively using CEM I cement [BS EN 197, 2000] with a characteristic strength of $30 \mathrm{~N} / \mathrm{mm}^{2}$ at 28 days and a w/c ratio of 0.50 .

The crumb rubber used in this study was manufactured from used tyres torn into smaller particles which can range from 0.425 to $4.75 \mathrm{~mm}$ in size [Ganjian et al. 2009]. The original tyres contained approximately $70 \%$ of recoverable rubber, $15 \%$ of steel, $3 \%$ of fibres and $12 \%$ of inert fillers. The raw rubber is sliced into $75 \mathrm{~mm}$ square pieces (granulation stage) followed by further breakdown until they pass through a $19 \mathrm{~mm}$ screen which are reduced to smaller sizes in a finishing mill to the required product size. Magnets and air separators are used throughout the process to remove steel wire, fabric and other metal contaminants. The crumb rubber used for this study has a nominal particle size of $3 \mathrm{~mm}$, as shown in Figure 3.

Both the fine and coarse aggregates were obtained from local sources in Ireland. The fine aggregate used was medium graded sand [BS EN 12620, 2007] and the coarse aggregate was crushed basalt with a maximum size of $10 \mathrm{~mm}$. Before mixing, the water absorption of the aggregates was determined and the water added to the concrete was adjusted accordingly. 


\subsection{Profiled Metal Deck}

The profiled metal deck used in this study was a ComFlor ${ }^{\circledR} 60$ (CF60) profiled steel deck. Table 3 presents the properties of the metal deck. The slabs were fitted with $19 \mathrm{~mm}$ shear studs welded onto the metal deck with different spacing's of 450 and 900mm (C-450, C-900, CRC-450, CRC-900).

\subsection{Preparation of concrete and testing samples}

The 130mm thick concrete toppings were directly cast on top of the metal deck in three equal depths compacted with a poker vibrator. The surface of the fresh concrete after compaction was troweled level. Ganjian et al [2009] highlighted the issue of rubber particles moving to the top of their testing moulds after vibrating. Non-uniform distribution of the rubber crumb in the concrete could result in failure at lower stresses. To avoid this, the top surface of the slab was initially levelled with a smooth length of timber to produce a rough finish and then trowelled level (Figure 4(a)).

Curing of the concrete was provided by placing the slabs under polythene sheets for 24 hours after mixing as shown in Figure 4(b).

Six $150 \mathrm{~mm}$ thick cubes were cast for compression strength testing at 7 and 28 days for each mix and one for Young's Modulus analysis. The cubes were cast in 50mm thick layers with each compacted with a poker vibrator and placed under plastic sheeting for 24 hours. Following demoulding, they were placed in a curing tank at $20 \pm 2{ }^{0} \mathrm{C}$ until testing.

Two 500x100x100mm deep beams were cast for each mix for flexural strength testing. The beams were cast in $50 \mathrm{~mm}$ thick layers, compacted with a poker vibrator and placed under plastic sheeting for 24 hours. Following demoulding, they were placed in a curing tank for 7 days at $20 \pm 2^{0} \mathrm{C}$. 


\subsection{Fresh concrete properties}

The workability of the concrete was measured in terms of slump and noted immediately after manufacture in accordance with BS EN 12390-2 [2000].

\subsection{Hardened concrete properties}

The compressive strength for each mix was determined using the $150 \mathrm{~mm}$ thick cubes in accordance with BS EN 12390-3 [2000].

The flexural strength of the two concretes was determined using four (two for each mix) 500x100x100mm deep beams in accordance with BS EN 12390-5 [2000] with the load applied at two points eqi-distant along the beam until failure. The test setup is shown in Figure 5.

The Young's Modulus of the two mixes was determined by subjecting a 150mm cube (one for each mix) to uniaxial loading in accordance with BS 1881-121 [1983] with the stress and strain readings recorded at each applied load using strain gauges as shown in Figure 6.

\subsection{Test set-up}

The study involved two sets of full scale composite slabs with a 130mm thick concrete topping, one with crumb rubber (7.5\% fine aggregate replacement level) and one without.

The composite slabs were simply supported on a testing frame with a $2500 \mathrm{~mm}$ clear span. The overhang distance 'Lo' for each support was 100mm with two symmetrically applied equal point loads over the full width of the slab. Figure 7 shows the arrangement before testing. 
Strain gauges were attached to the underside of the steel deck soffit (Figure 8(a)) and on top of the concrete slab at mid-span (Figure 8(b)) to monitor the structural behaviour of the test specimens during loading. The gauges were applied by firstly sanding down the zinc coating on the metal deck, cleaned and then glued onto the steel surface. The strain gauge at the top of the concrete slab at mid-span was attached in the same matter as shown in Figure 6 for the Young's Modulus test.

A nominal reinforcement of A142 mesh $(0.1 \%$ of the cross-sectional area of the concrete slab) was cast with a $25 \mathrm{~mm}$ cover all around the perimeter of the slab. Crack inducers were placed across the full width of the specimen in the tension zone of the concrete. They were fabricated from $0.6 \mathrm{~mm}$ steel sheeting and cut into the trapezoidal shape of the profiled steel deck. The crack inducers extended from the bottom of the deck to the underside of the mesh above. The inducers were rubbed down with de-bonding agent before the fresh concrete was poured into the shutter to define the shear span length (Ls) under loading. They also eliminated the tensile resistance provided by the concrete in the zero shear area under load. Figure 9 presents the arrangement before the concrete was poured.

The relative end slip between the concrete and profiled steel deck was measured at both ends using two transducers, as shown in Figure 10. The mid-span deflection was also measured using a transducer, as shown in Figure 11.

\subsection{Loading arrangements}

Similar to the fresh and hardened concrete tests, the structural testing regime employed on the composite slabs for this study followed the recommendations in Eurocode 4 [2004] to provide confidence to the results, particularly for the CRC slabs.

Eurocode 4 [2004] recommends that the specimens be subject to cyclic loading to remove the chemical bond between the steel and concrete interface prior to static loading. By having the interface removed, slip is initiated and the shear bond strength value can be calculated from the static loading data between the slab and the metal deck. However, according to Marmuthu 
et al. [2007], the cyclic loading proposed in Eurocode 4 does not affect the load carrying capacity of the slab and found a minimal difference between the shear bond strength of a composite slab subjected to cyclic loading followed by static loading to failure than static loading alone. Research conducted into the shear bond capacity of composite slabs using this procedure [Mohammed et al. 2010; Marmuthu et al, 2007] found that cyclic loading beforehand had a negligible effect on the eventual load carrying. It was therefore decided not to conduct cyclic testing before the static tests.

For the static test, the slabs were positioned into the testing rig (Figure 12(a)) over the supports (Figure 12(b)) with a forklift. The 254 x 146 UB31 spreader beam (Figure 12(c)) transferred the applied load equally over the full width of the slabs and gradually increased so the specimen would not fail within one hour of application as outlined in Eurocode 4 [2004].

\section{EXPERIMENTAL RESULTS}

\subsection{Workability}

Figure 13 shows the measured slumps for the two mixes. As shown, both were similar with a slightly higher slump seen in the control concrete. Khatib and Bayomy [1999] and Tata [2008] reported that with an increasing CRC content, the slump was found to decrease due to reduced inter-particle friction between the rubber and other mix constituents as well as the lower unit weight of the plastic mix [Tata et al, 2008]. Khaloo et al [2008] found that when rubber crumb is used as a fine aggregate replacement, the slump may increase up to a maximum value of $15 \%$.

\subsection{Compression Strength}

As shown in Figure 14, there is a decrease in compressive strength in the CRC, as expected, which is consistent with previous research [Li et al., 1998; Eldin and Senouci, 1993; Gangian et al., 2009]. There is also a corresponding decrease in weight and density (see Table 4) 
previously observed by Khatib and Bayomy [1998]. This is due to the lower relative density of the CRC than natural aggregates. Najim and Hall [2010] have shown that significant reductions in compressive strength can be avoided when the crumb rubber replacement level does not exceed between 20 and $30 \%$ of the total aggregate content and are minimised below $15 \%$.

\subsection{Flexural Strength}

The average flexural strength results are presented in Figure 15 with the CRC yielding an increased flexural strength. This does not concur with previous work in this area by Li et al [1998] and Aiello and Leuzzi [2010] who both report a reduction in flexural strength with the addition of CRC and concluded that it can undergo larger deformations before failure compared to conventional concrete control samples.

The type of beam failure experienced by each concrete was also noted. As may be seen in Figure 16(a), the control concrete had a brittle failure initiating in the tension zone at midspan followed by a vertical crack upwards. However, the CRC beams experienced a ductile failure which provides a higher capacity to absorb plastic energy under both compression and tensile loading. It was observed here that the failure cracks were wider for the CRC beams (Figure 16(b)) which are another indication of ductile behaviour as the tensile strain energy being transferred to the rubber crumb particles.

\section{$3.4 \quad$ Young's Modulus}

Figure 17 show the results from the Young's Modulus tests. As may be seen, the Young's modulus of the control concrete $\left(19.76 \mathrm{kN} / \mathrm{mm}^{2}\right)$ is higher than the $7.5 \%$ CRC sample $(12.96$ $\mathrm{kN} / \mathrm{mm}^{2}$ ). This reduction in Young's modulus has been observed previously [Li et al, 1998; Atahan \& Sevim, 2008]. 


\subsection{Specimen load testing}

The failure loads and mechanisms during testing are described in Table 5. As the composite slabs were subjected to vertical loading they are most likely to suffer from longitudinal shear failure which occurs when diagonal shear cracks develop in close proximity to concentrated loads. This is typically followed by longitudinal slip between the concrete and metal deck in the constant shear zone of the composite slab. Figures 18 to 21 shows examples of the diagonal cracking, end slip and deformed shape during testing with longitudinal shear failure observed for all composite slab test specimens.

\subsection{Bottom strain measurements on the metal deck}

Figure 22 presents the recorded tension strain readings of the profiled sheeting at mid-span as the load was applied. As shown, the trends of the measured tension strains are similar for all slabs. The composite action of the C-450 and C-900 slabs is lost at 20 and $8 \mathrm{kN}$ respectively as indicated by the 'jump' in strain. When this occurs, the full composite action is lost with only partial interaction between the two occurring with an increase in the rate of tensile strain.

For the CRC slabs, the loss of composite action is deemed to have occurred at loads of 24 and $11.3 \mathrm{kN}$ for the 450 and $900 \mathrm{~mm}$ shear spans respectively as indicated by the 'jump' in strain reading. This retention of chemical bond and higher strains may be explained by the higher ductility of CRC as shown in the flexural strength results above. It was also expected that the CRC slabs would yield at lower loads than the control due to their reduced compressive strengths. However, as indicated, the CRC provided a higher failure load, and, based on the linear elastic relationship as shown in the strain readings up to the point of bond loss, the CRC exhibits a better composite action.

Strain measurements of the profiled steel sheeting under static load taken by Mohammed [2010] showed that CRC slabs attained higher strains and yielded at lower loads than conventional concrete composite slabs. This behaviour was attributed to the high ductility of $\mathrm{CRC}$ and the creation of an improved composite action with the ductile profiled steel deck. 
3.7 Top strain measurements on the metal deck

Figure 23 shows the measured compressive strain readings of the concrete slab at mid-span during loading.

The compressive strain curves are similar for both concretes with the C-450 and C-900 slabs losing their bond at loads of 20 and $12 \mathrm{kN}$ respectively which corresponds well with the tensile strain of the steel. As the strain indicates linear-elastic behaviour, it can be concluded that full composite action has ceased and partial interaction has begun with an increase in the rate of compressive strain.

It is assumed that the bond for the CRC has been lost at loads of 24 and $11.3 \mathrm{kN}$ with no sudden increase in strain. It is clear that the CRC slabs have a greater and more rapid increase in compressive strain than the control due to its improved ductility and being capable of absorbing higher strain energies.

\subsection{Mid-span deflection}

Figure 24 shows the recorded mid-span deflections during loading. As expected, the CRC slabs have higher deflections than the control due to the enhanced ductility, lower rigidity and higher modulus of elasticity. However, this difference between defections is less in the longer shear span. Marimuthu et al [2007] observed two types of load-deflection in shorter shear spans (320-380mm) where shear cracks formed near the loading locations and a reduction in load was observed Following this, an increase in load (and rate of deflection) was detected with subsequent flexural failure of the specimen. Similar behaviour was noted in longer shear spans $(850-1150 \mathrm{~mm})$ with visible cracking between loading points and a reduction in load carrying capacity.

Mohammed [2010] observed that, unlike longer shear spans, shorter shear spans were undergoing combined differential movement between steel and concrete steel interface and displacement under loading. CRC slabs were found to have lower initial elastic deflections 
compared to conventional concrete which was attributed to the lower tangential modulus of elasticity.

\subsection{End slip}

The relative end slip between the concrete and profiled steel deck was measured at both ends using transducers as shown in Figures 25 and 26 which indicate when the slabs exhibited ductile behaviour.

The shorter shear spans $(450 \mathrm{~mm})$ experienced a greater slip at lower loads due to the interface between the concrete and profiled steel deck being lost at lower applied loads. The short shear span length indicates a linear elastic deflection as the rate of slip increases following the loss of bond. Slippage was greater for the CRC-450 slab as it has a lower modulus of elasticity due to its lower rigidity. However, the adherence between the concrete and profiled steel deck was lost at higher loads for the longer shear spans where the linear elastic phase continued as the rate of slip increased after the loss in bond.

Marimuthu et al [2007] also observed that end slip was minimal during early loading in shorter shear spans, where, following the appearance of the first crack, the rate increases. The authors concluded that this demonstrated a loss in bond between the profiled sheeting and the concrete slab and both behaves independently of each other. In their longer shear span specimens, slip was greater with similar curves to the shorter spans.

Mohammod [2010] also observed minor end slippage early on in tests with shorter shear lengths $(450 \mathrm{~mm})$. Cracking was heard and longitudinal cracks were detected as the load was increased with a loss of bond between the steel and concrete. For longer shear lengths $(900 \mathrm{~mm})$, while a slight end slippage was observed, neither cracks nor signs of failure were detected. As the load increased, longitudinal cracks formed at the steel-concrete interface at both ends of the slab with a sudden rise of end slippage. Cracking continued from the interface upwards towards the loading points leading to separation of the two materials and it ceased to behave compositely. 
It has been reported [Ganjian et al, 2009] that rubber particles in concrete can migrate to the top of test moulds after vibration which can lead to non-uniform distribution and premature failure at lower stress levels. As crumb rubber particles are hydrophobic, one might expect them to coagulate and flock together along the top surface after vibration. To confirm this, samples from the slabs were broken off following testing and a visual inspection confirmed that a satisfactorily dispersal of the particles did occur.

\subsection{Classification of failure}

It is considered in Eurocode 4 that the longitudinal shear behaviour is ductile if the failure load exceeds that causing an end slip of $0.1 \mathrm{~mm}$ by more than $10 \%$. If the maximum load is reached with a mid-span deflection exceeding L/50, the failure load should be taken as that causing a mid-span deflection of L/50. Therefore, considering this, ductile behaviour is the cause of failure here. For brittle behaviour, a reduction factor of 0.8 must be applied to the maximum experimental shear force of the slab [Eurocode 4, 2004] where it will have a reduced calculated load carrying capacity. A ductile behaviour will ensure the composite slab will be designed for optimum usage in terms of load carrying capacity.

\subsection{Longitudinal Shear Capacity}

Shear connection in composite design depends on the interconnection between the concrete and steel components with sufficient strength and stiffness for them behave as a single structural member [Eurocode 4 2004]. As the shear interaction of composite slabs is complex to analyse (particularly for the wide range of profiled decks available), full scale bending tests are required which can be expensive and time consuming. However, two numerical methods are available to calculate the shear connection in composite components, namely the m-k (semi-empirical) and partial shear connection (PSC) methods (analytical) using the longitudinal shear failure loads. These methods are used here to demonstrate that CRC composite slabs have similar longitudinal shear capacities as conventional concrete. 
The m-k method (where $\mathrm{m}$ refers to the mechanical interlock between concrete and profiled deck and $\mathrm{k}$ represents the frictional between both) can determine the shear connection of composite slabs from loading tests carried out on simply-supported composite slabs. The method relates the composite slab shear strength to the actual geometry of the component (Annex B, Eurocode 4, 2004). Longitudinal shear failures typically commence when a diagonal crack appears underneath one of the concentrated loads in the constant shear zone which is associated with a loss of bond along the shear span 'Ls' and a measurable 'jump' in slip at the end. If this leads to a sudden failure, the shear connection between the concrete and steel profiled deck can be classified as brittle (Annex B, Eurocode 4, 2004).

Johnson [1994] developed the expression shown in Equation 1 to calculate the longitudinal shear resistance using the m-k method, where $V_{t}$ is the maximum shear force $(\mathrm{N}), b$ is the width of the composite slab $(\mathrm{mm}), d_{p}$ is the effective depth of the slab $(\mathrm{mm}), m$ is the mechanical interlock between the materials (slope of conventional and CRC lines as Figure 27 (197.14 and $249.28 \mathrm{~N} / \mathrm{mm}^{2}$ respectively), $A_{p}$ is the effective cross-sectional area of the metal deck $(\mathrm{mm} 2), L_{s}$ is the shear span $(\mathrm{mm})$ and ${ }_{\mathrm{k}}$ is the frictional force between the concrete and steel deck (y-intercept in Figure 27, 0.1602 and $0.0249 \mathrm{~N} / \mathrm{mm}^{2}$ for the conventional and CRC respectively).

Using the loading results above and the values in Table 6 and 7, the longitudinal shear resistance $\left(\sigma_{\mathrm{u}, \mathrm{Rd}}\right)$ using the m-k method for the conventional and CRC slabs with spacing's of 450 and $900 \mathrm{~mm}$ is given as $0.72 \mathrm{~N} / \mathrm{mm}^{2}, 0.73 \mathrm{~N} / \mathrm{mm}^{2}, 0.44 \mathrm{~N} / \mathrm{mm}^{2}$ and $0.38 \mathrm{~N} / \mathrm{mm}^{2}$ respectively and shown in Figure 27. Considering that the CRC produced lower compressive strengths (as expected), its performance in terms of bending and longitudinal shear resistance is shown to be comparable to conventional concrete.

$$
\sigma_{u, R d}=\frac{V_{t}}{b d_{p}}=m\left(\frac{A_{p}}{b L_{s}}\right)+k
$$

Equation 1

Johnson [1994] also developed the expression shown in Equation 2 to calculate the longitudinal shear resistance using the PSC method where $\eta$ is the degree of interaction, $N_{c f}$ 
is the full shear connection, $b$ is the width of the composite slab $(\mathrm{mm}), L_{s}$ is the shear span $(\mathrm{mm})$ and $L_{o}$ is the length of the overhang $(\mathrm{mm})$.

Using the loading results above and the values in Table 6, 8 and 9, the longitudinal shear resistance $\left(\sigma_{\mathrm{u}, \mathrm{Rd}}\right)$ using the PSC method are given as $0.29 \mathrm{~N} / \mathrm{mm}^{2}$ and $0.22 \mathrm{~N} / \mathrm{mm}^{2}$ respectively and shown in Figure 28 with slabs classified as ductile again.

$$
\sigma_{u, R d}=\frac{\eta N_{c f}}{b\left(L_{s}+L_{0}\right)}
$$

Equation 2

These small differences are consistent results from others [Hedaoo et al, 2012; Mohammed, 2010] using similar CRC replacement levels. Mohammed [2010] calculated a longitudinal shear resistance of $0.24 \mathrm{~N} / \mathrm{mm}^{2}$ for his $10 \%$ CRC composite slabs with similar compressive strengths $\left(28.9 \mathrm{~N} / \mathrm{mm}^{2}\right)$, Young's modulus $\left(14.5 \mathrm{kN} / \mathrm{mm}^{2}\right)$ and flexural strengths $\left(3.7 \mathrm{~N} / \mathrm{mm}^{2}\right)$.

\section{CONCLUSIONS}

This paper presents a practical structural application of crumb rubber from discarded car tyres in concrete toppings on composite metal deck slabs.

Results from a number of small and full-scale tests have shown that CRC composite slabs produce similar longitudinal shear capacities due to its ductile behaviour and greater capacity to absorb higher tensile stresses. The results have shown that the interface between the concrete and steel maintains shear interaction under vertical loading while also resisting longitudinal slip at higher loads.

The longitudinal end slip results here also satisfy the recommendations within Eurocode 4 with all slabs displaying ductile behaviour. With further improvements to the compressive, flexural and tensile strengths of CRC, based on the results here, these slabs have the potential 
to be a structurally viable form of construction while successfully addressing the environmental problem created by tyre rubber. 


\section{REFERENCES}

Abdullah, R. (2004). Experimental Evaluation and Analytical Modeling of Shear Bond in Composite Slabs, Dissertation for Doctor of Philosophy in Civil Engineering, Faculty of the Virginia Polytechnic Institute and State University.

Aiello, M.A and Leuzzi, F. (2010). Waste tyre rubberized concrete: Properties at fresh and hardened state, Waste Management, Vol. 30, 1696-1704.

Atahan, A. O. and Sevim, U. K. (2008). Testing and comparison of concrete barriers containing shredded tire chips, Materials Letters, Vol. 62, 3754- 3757.

Bravo, M. and Brito, J. (2012). Concrete made with used tyre aggregate: durability-related performance, Journal of Cleaner Production, Vol. 25, 43- 50.

BS EN 12390-3 (2000) Testing hardened concrete - Part 3: Compressive strength of test specimens.

BS EN 12390-5 (2000) Testing hardened concrete - Part 5: Flexural strength of test specimens.

BS EN 12390-2 (2000) Testing fresh concrete - Part 2: Slump test.

BS EN 12620 (2007), Aggregates for concrete British-Adopted European Standard.

BS 1881-121 (1983) Testing concrete. Method for determination of static modulus of Elasticity in compression. 
BS EN 197-1 (2000), Cement: Composition, Specifications and Conformity Criteria for Common Cements, British Standards Institution, London.

Eldin, N. N., Senouci, A. B. (1993). Rubber-tire particles as concrete aggregates, ASCE Journal of Materials in Civil Engineering 5(4), 478-496.

Eurocode 4: BS EN 1994-1-1:2004, Design of composite steel and concrete structures - Part 1-1: General rules and rules for buildings.

Fattuhi, N. \& Clark, L. (1996), Cement-based materials containing shredded scrap truck tyre rubber, Construction and Building Materials, Vol. 10 (4): pp. 229-236.

Ganjian, E, Khorami, M and Maghsoudi, A A, (2009). Scrap-Tyre-Rubber Replacement for Aggregate and Filler in Concrete, Construction and Building Materials, 23(5), pp. 1828-36.

Hedoo, N. A., Gupta, L. M. and Ronghe, G. N. (2012). Design of composite slabs with profiled steel decking: a comparison between experimental and analytical studies, International Journal of Advanced Structural Engineering, Vol. 4(1).

Johnson, R. P., (1994), Composite structures of steel and concrete: Beams, slabs columns, and frames for buildings, Vol. 1, 2nd edition, London: Blackwell Publishing.

Khaloo A. R, Dehestani, M and Rahmatabadi, P. (2008). Mechanical properties of concrete containing a high volume of tire-rubber particles, Waste Management; 28(12), 2472-82.

Khatib, Z. K. and Bayomy, F. M. (1999). Rubberized Portland Cement Concrete, Journal of Materials in Civil Engineering, pp. 206-213. 
Li, Z., Li, F. and Li, J. S, (1998). Properties of Concrete Incorporating Rubber Tyre Particles, Magazine of Concrete Research, Vol. 50(4), 297- 304.

Marimuthu, V., Seetharaman, S., Jayachandran S. A., Chellappan, A., Bandyopadhyay, T. K. and Dutta, D. (2007). Experimental studies on composite deck slabs to determine the shearbond characteristic (m-k) values of the embossed profiled sheet, Journal of Constructional Steel Research, Vol. 63, 791-803.

Mohammed, B. S. (2010). Structural behavior and $\mathrm{m}-\mathrm{k}$ value of composite slab utilizing concrete containing crumb rubber, Construction and Building Materials, Vol. 24, 1214-1221.

Mullett, D.L., (2000), Composite floor systems, The Steel Construction Institute, Blackwell Science Publishing.

Najim, K.B and Hall, M.R. (2010). A review of the fresh/hardened properties and applications for plain- (PRC) and self-compacting rubberised concrete (SCRC), Construction and Building Materials, 24, 2043-2051.

Nehdi, Moncef and Ashfaq, (2001). Cementitious Compositions Containing Recycled Tire Rubber: An Overview of Engineering Properties and Potential Applications, Cement, Concrete and Aggregates, Vol. 23(1), pp. 3-10.

Raghavan, D, Huynh, H and Ferraris, C. F. (1998). Workability, mechanical properties, and chemical stability of a recycled tyre rubber-filled cementitious composite, Journal of Materials Science, Vol. 33, 1745- 1752.

Siddique, R. and Naik, T. (2004). Properties of concrete containing scrap-tire rubber - an overview, Waste Management, Vol. 24, 563- 539. 
Taha M. Asce M., El-Dieb A.S., Abd El-Wahab, M. A and Abdel-Hameed M. E. (2008). Mechanical, fracture, and microstructural investigations of rubber concrete. Journal of Materials in Civil Engineering, 20(10), 640-9. 


\section{LIST OF FIGURES}

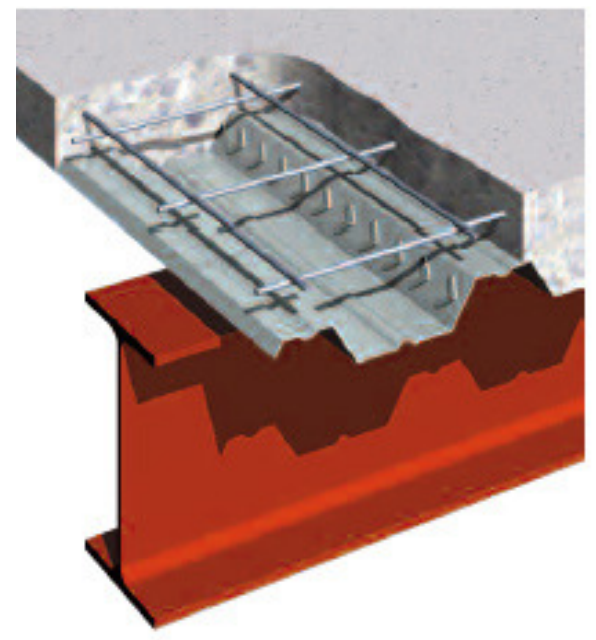

Figure 1 Typical profiled metal deck with concrete topping and anti-crack reinforcement

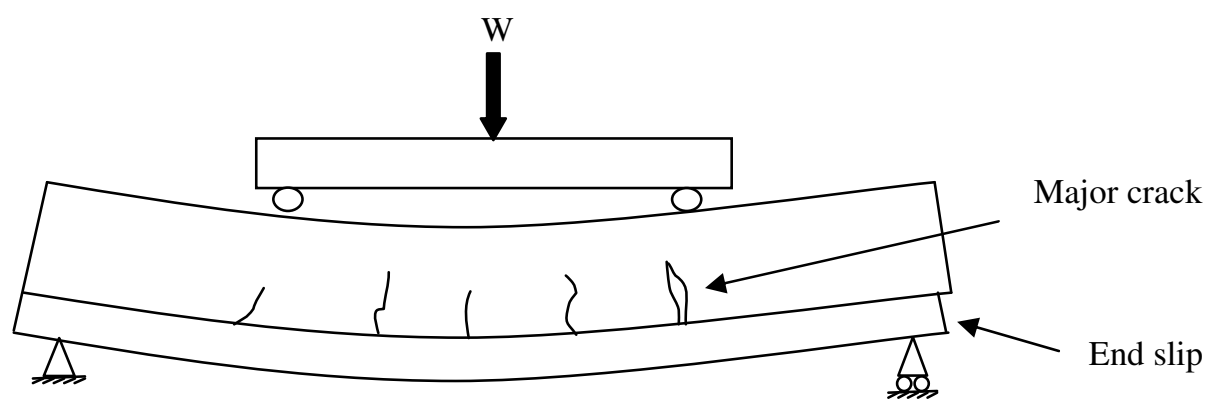

Figure 2 Diagonal shear cracks and longitudinal slippage 


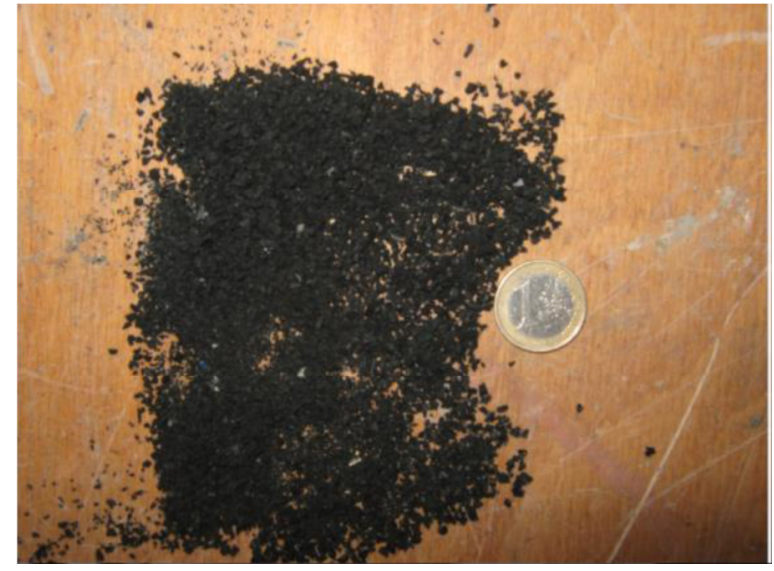

Figure $33 \mathrm{~mm}$ crumb rubber particle used in concrete
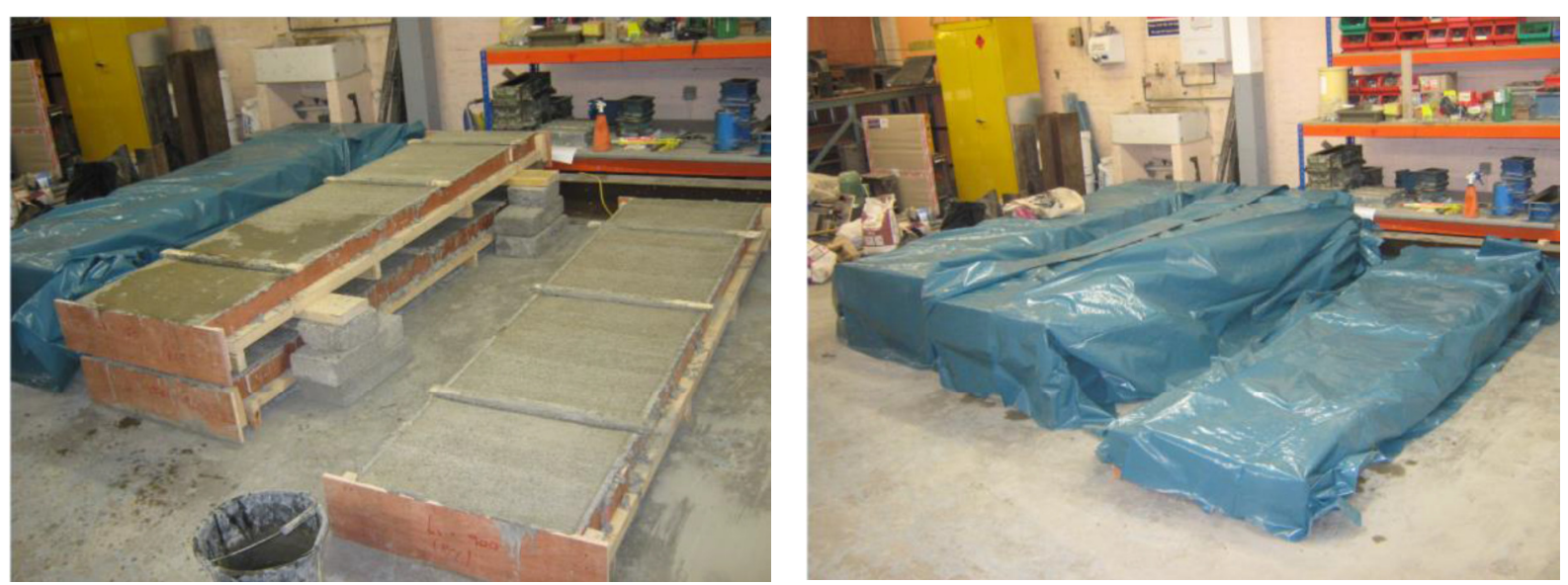

Figure 4

(a) Cast composite slab and (b) curing under polythene

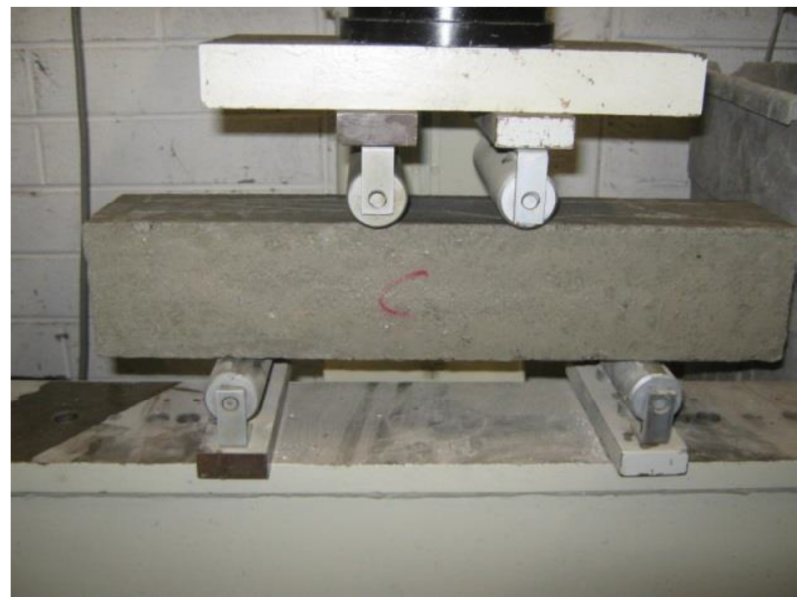

Figure 5 Test setup for the flexural test 


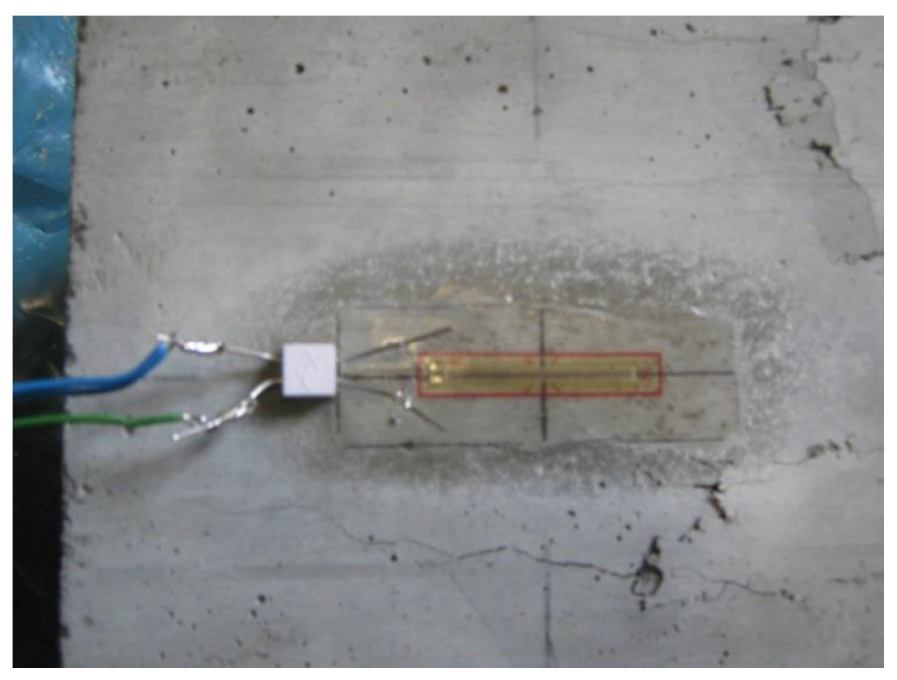

Figure 6 Test setup for determining the Young's Modulus

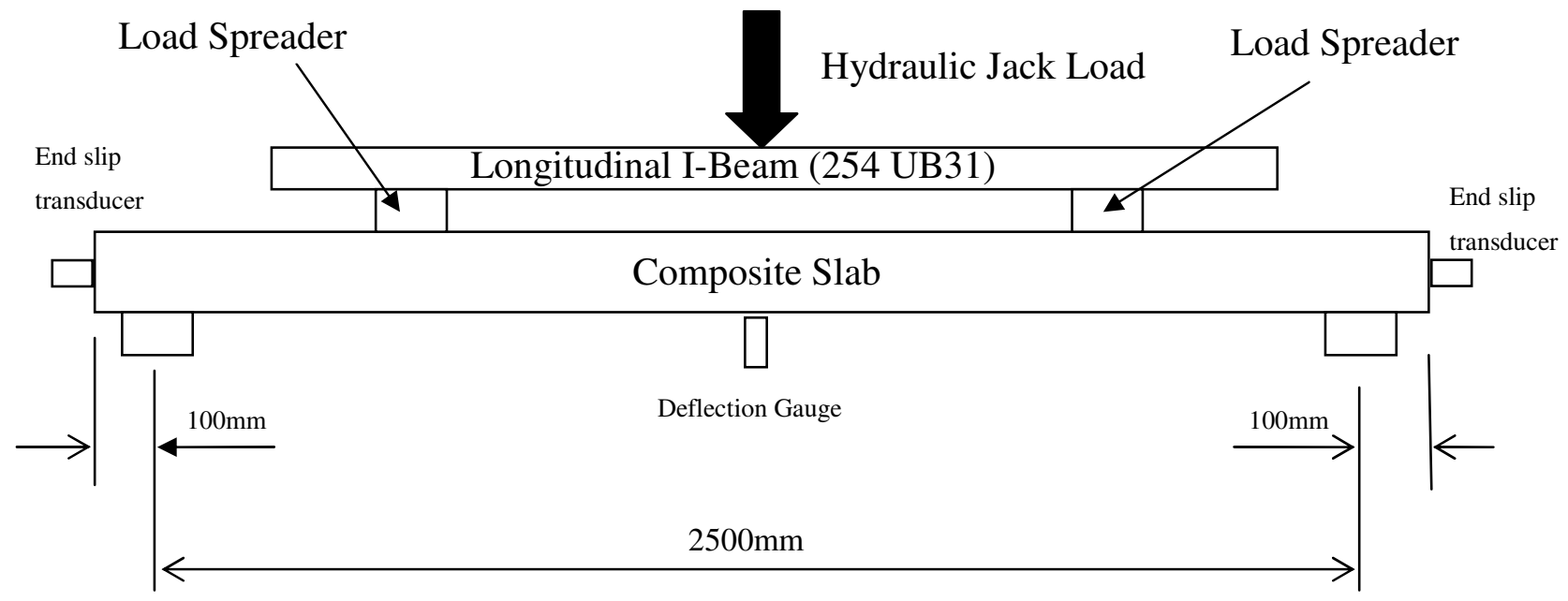

Figure 7 Positioning of the composite slabs in the test rig 


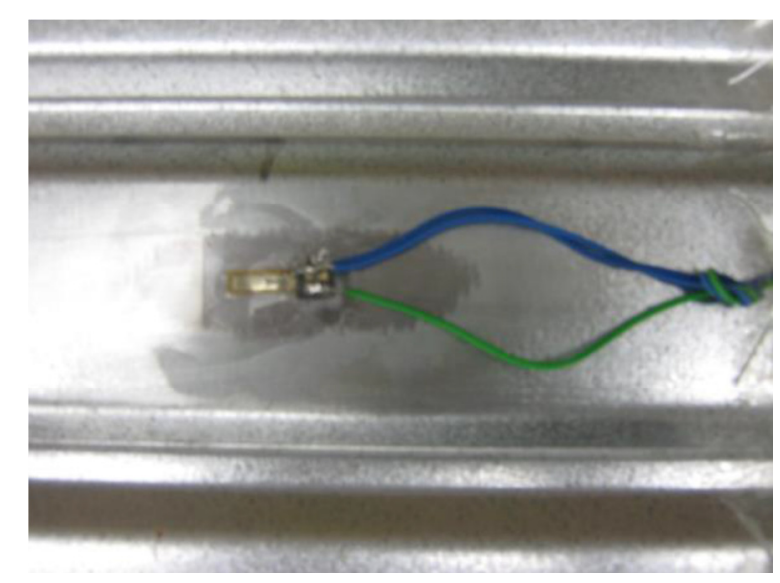

(a)

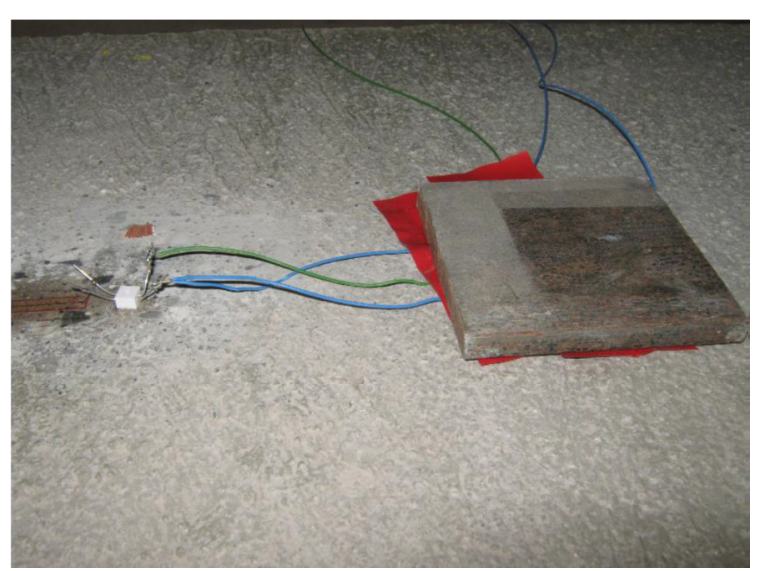

(b)

Figure 8 Strain gauges positioned on (a) metal deck and (b) on top of the concrete topping
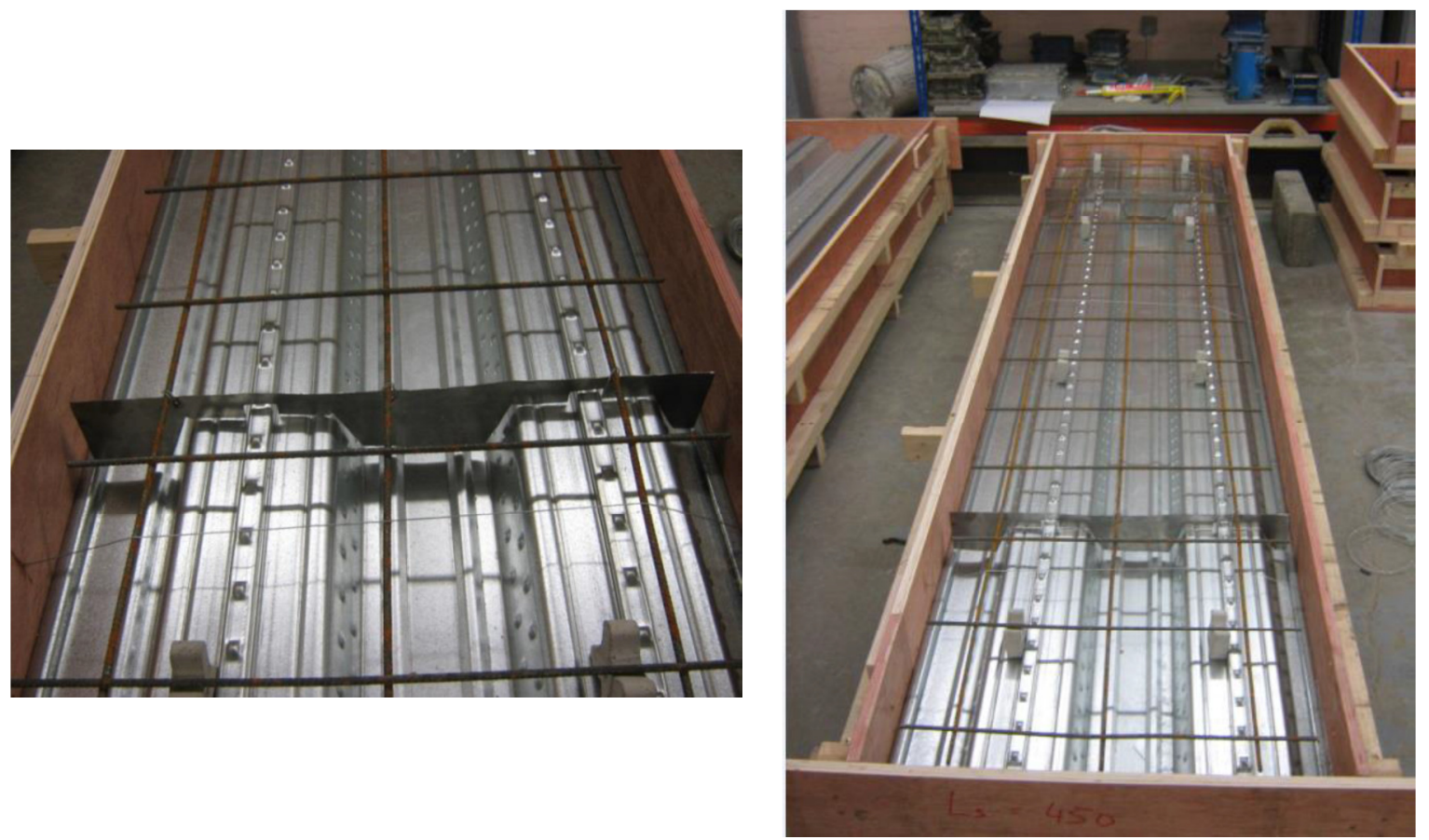

Figure 9 Formwork, crack inducers, spacers, A142 mesh fabric and profiled metal deck prior to concrete casting 


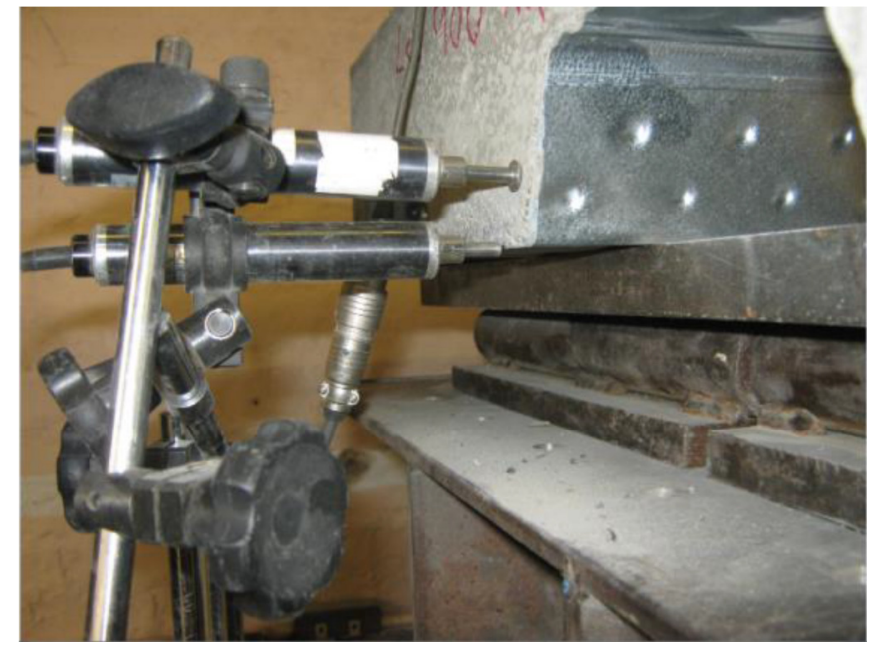

Figure 10 Transducers used to measure the relative end slip of the slabs

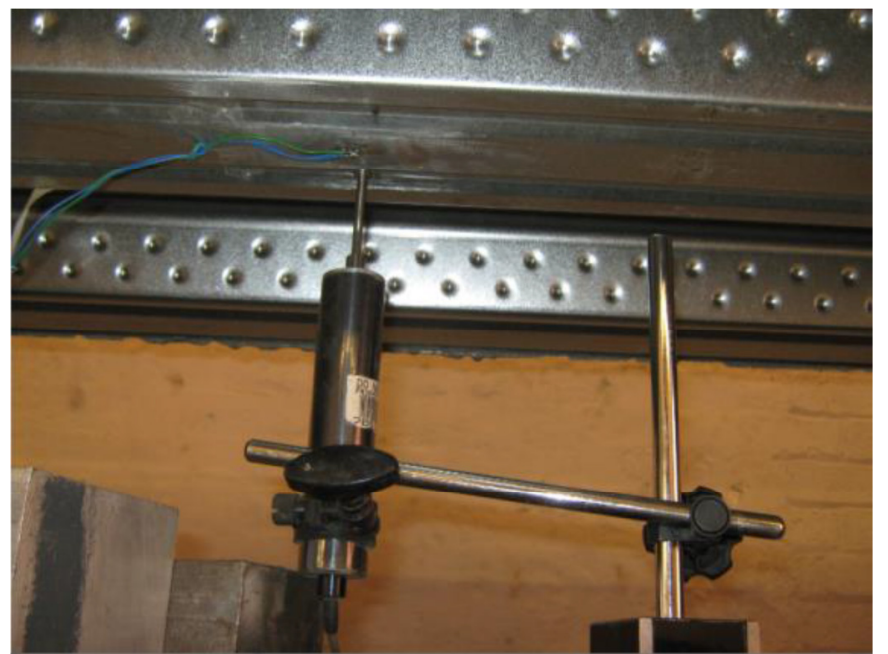

Figure 11 Transducers used to measure the mid-span deflection 


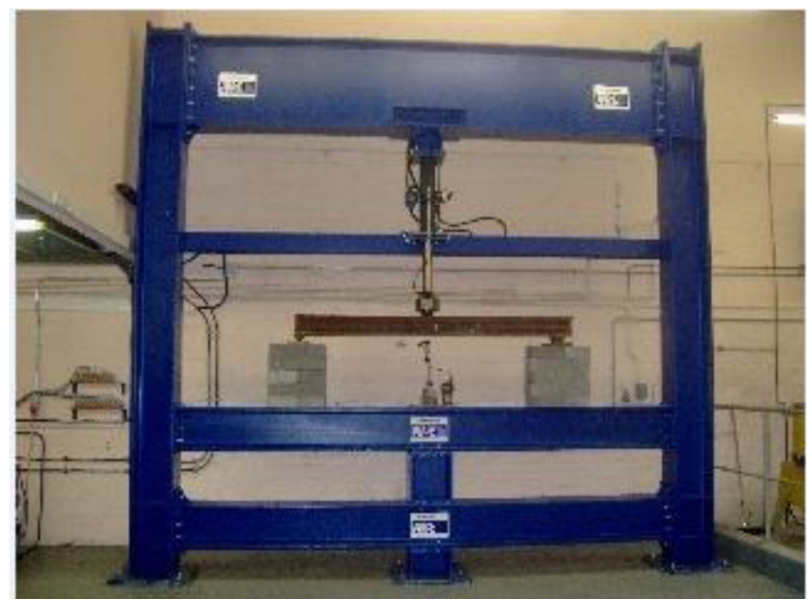

(a)

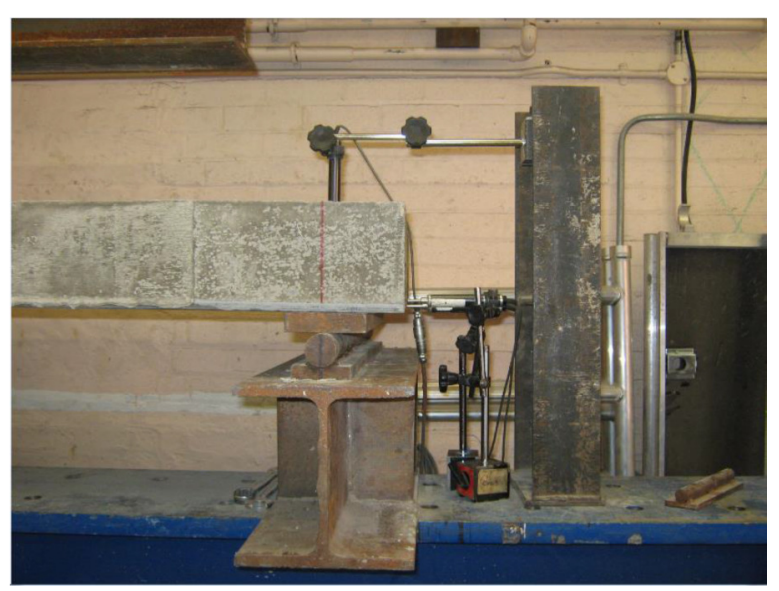

(b)

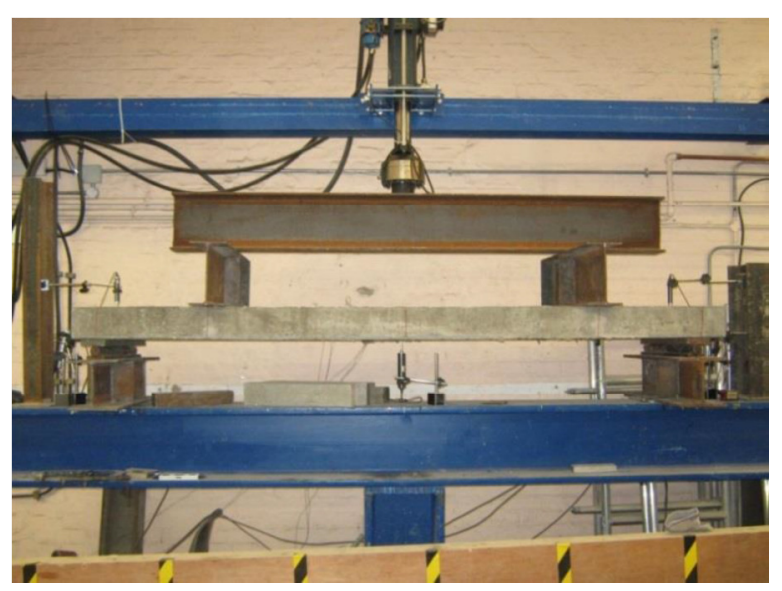

(c)

Figure 12 (a) Testing rig (b) positioning over the supports and (c) spreader beam applying the load over the width of the slabs 


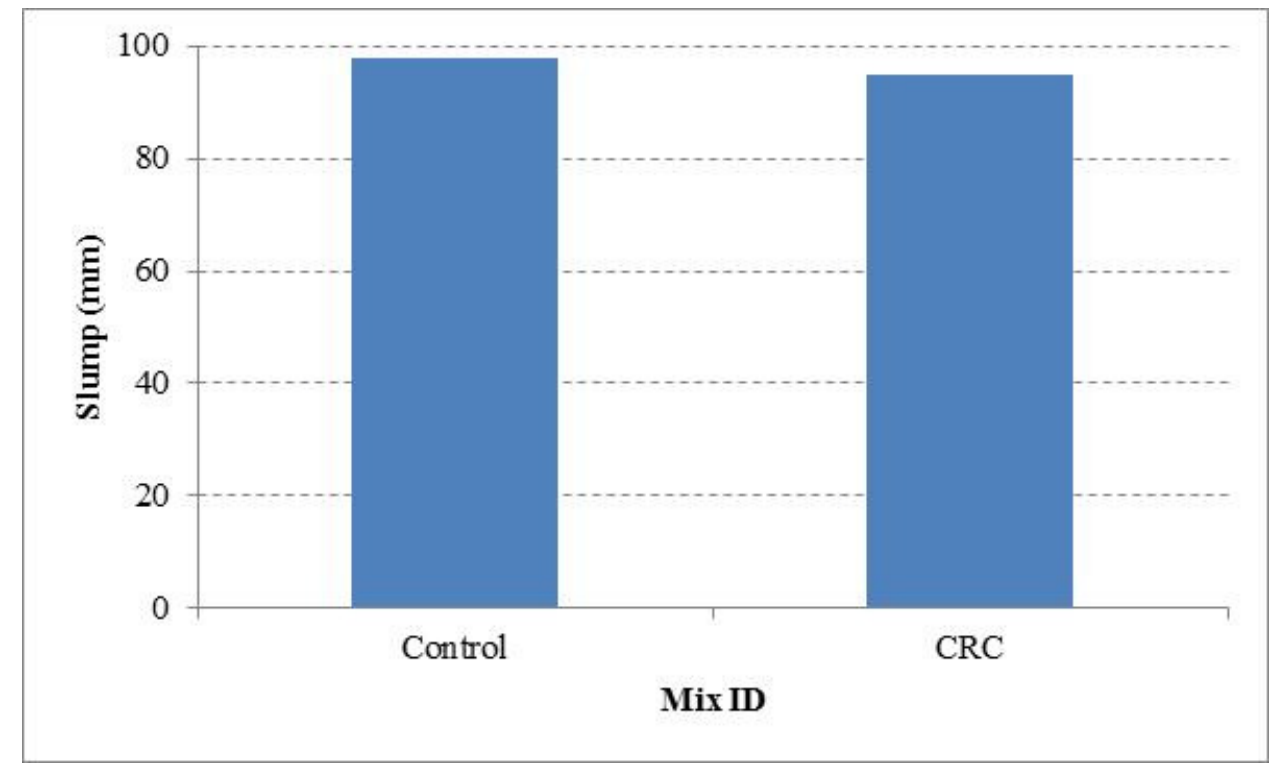

Figure 13 Measured workability results

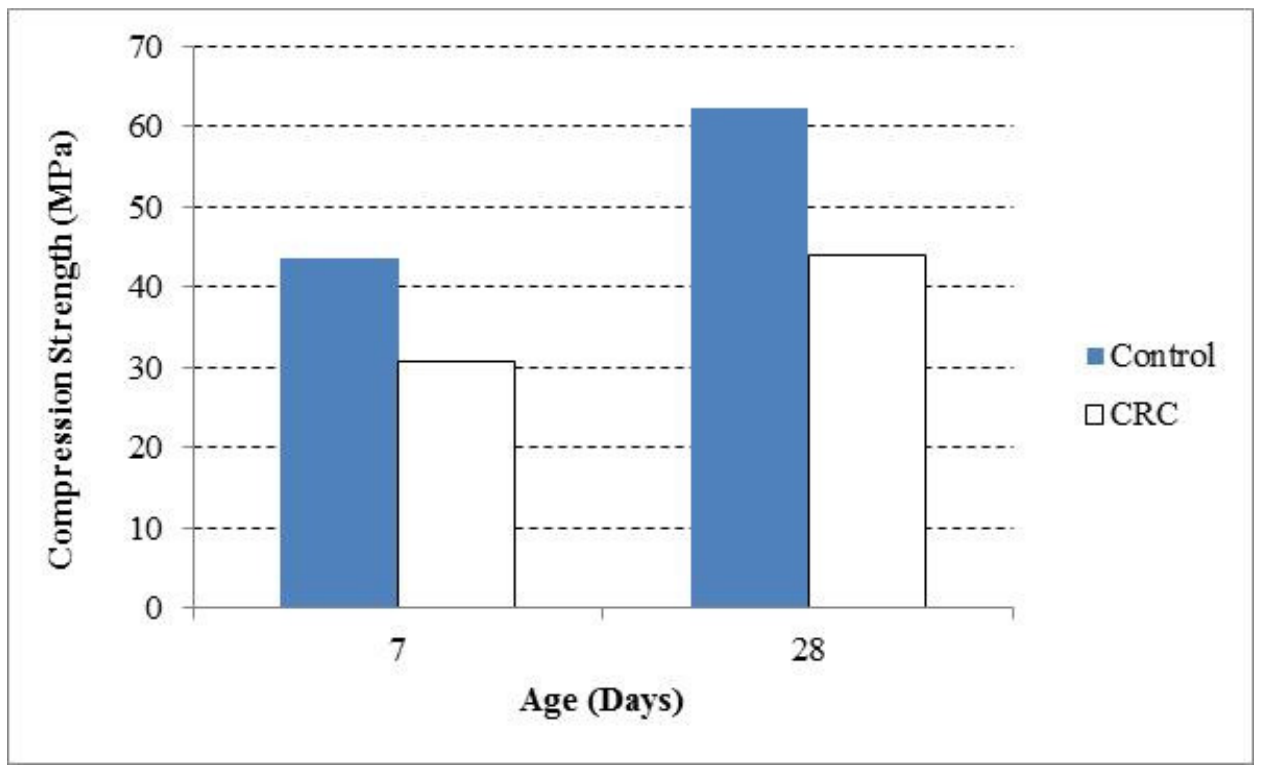

Figure 14 Compression strength results 


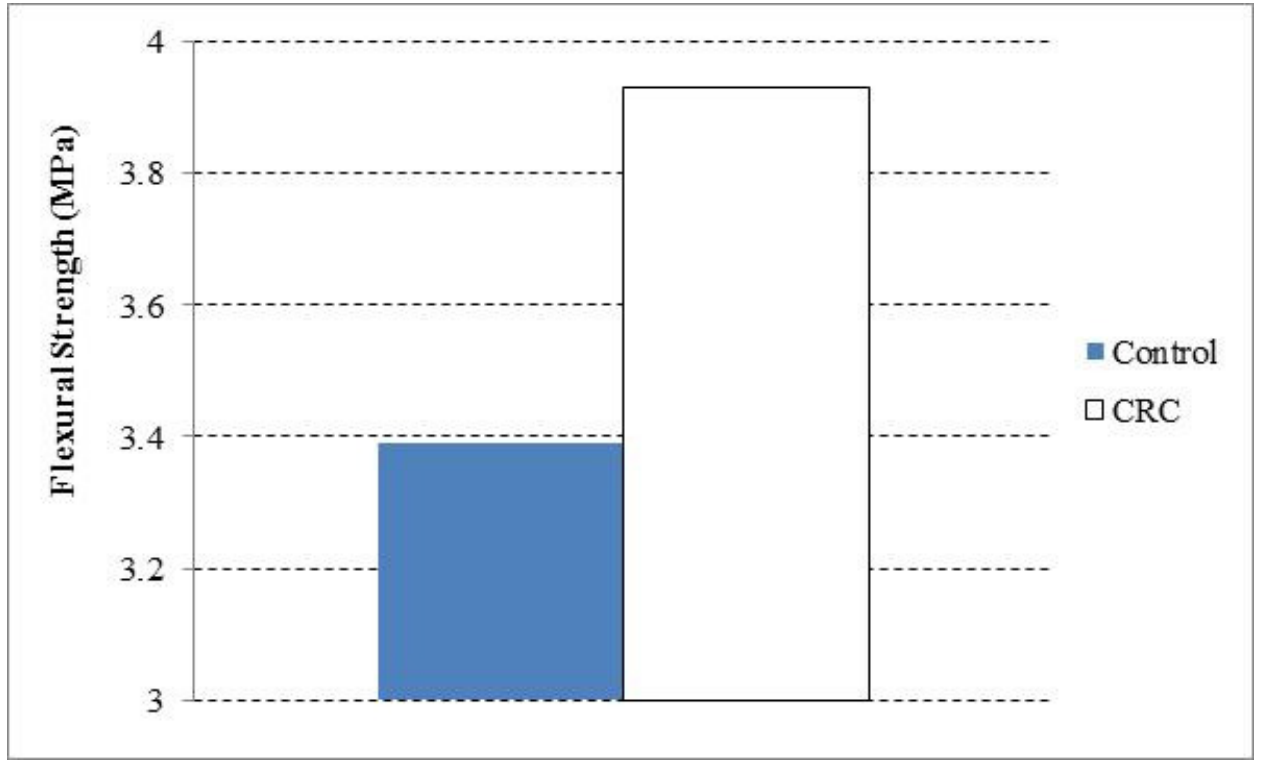

Figure $15 \quad$ Flexural strength results 

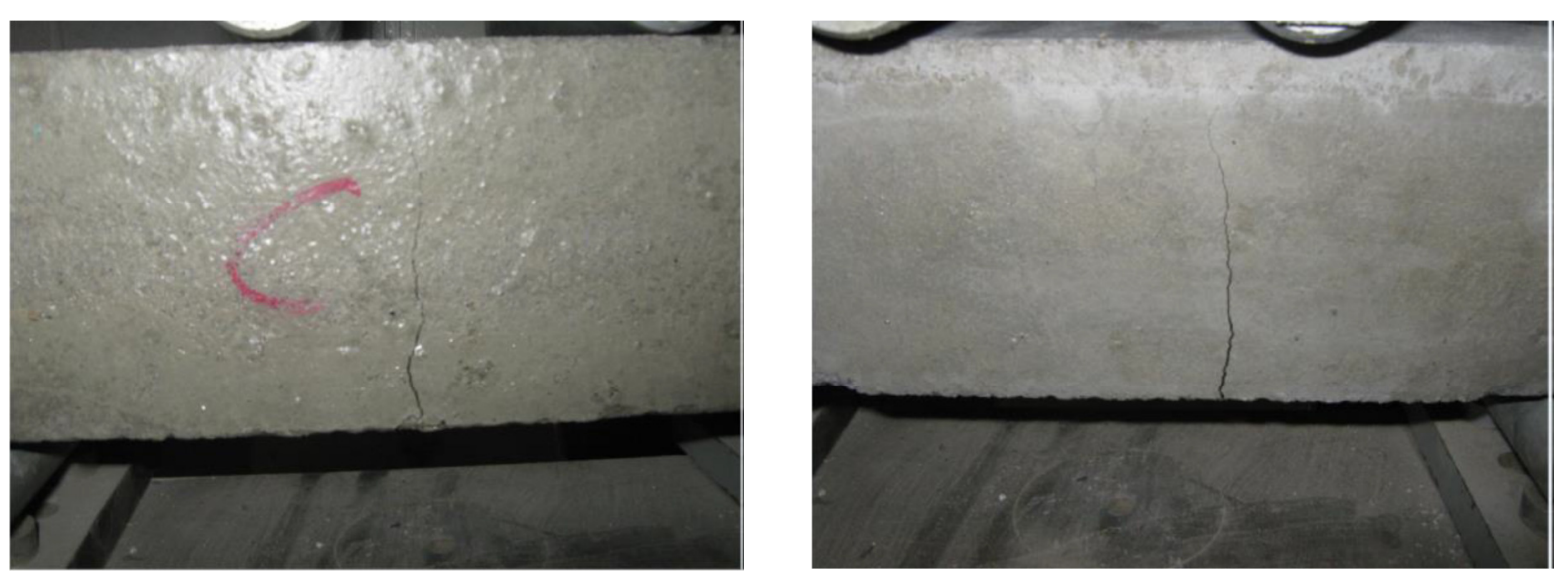

(a)
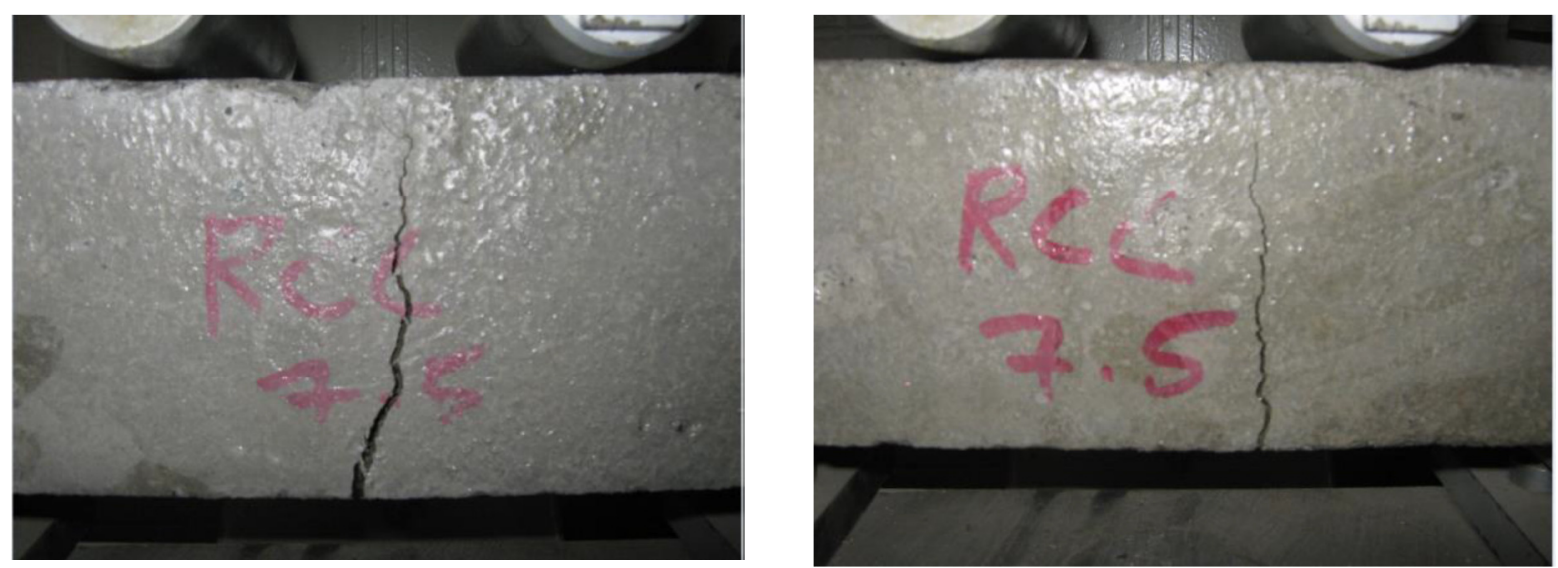

(b)

Figure 16 Cracks in (a) the Control and (b) the CRC beams following the flexural tests 


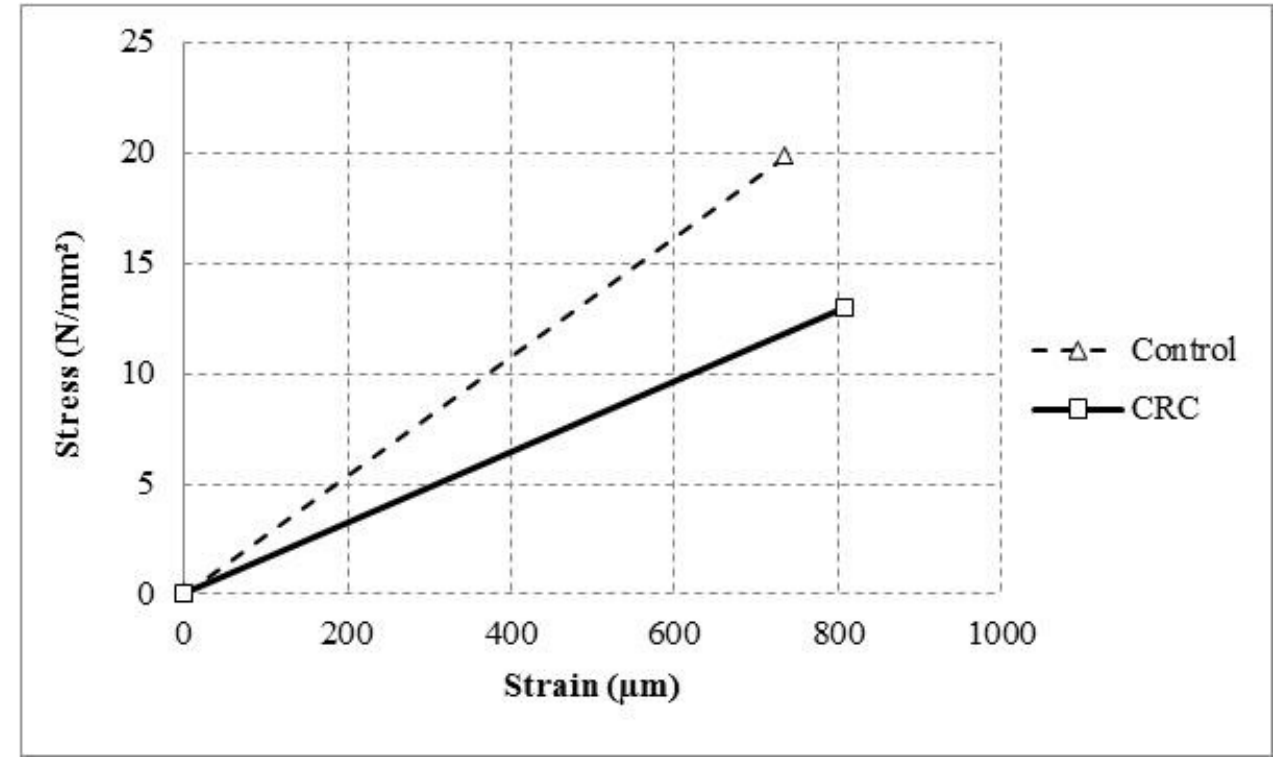

Figure $17 \quad$ Young's Modulus results 


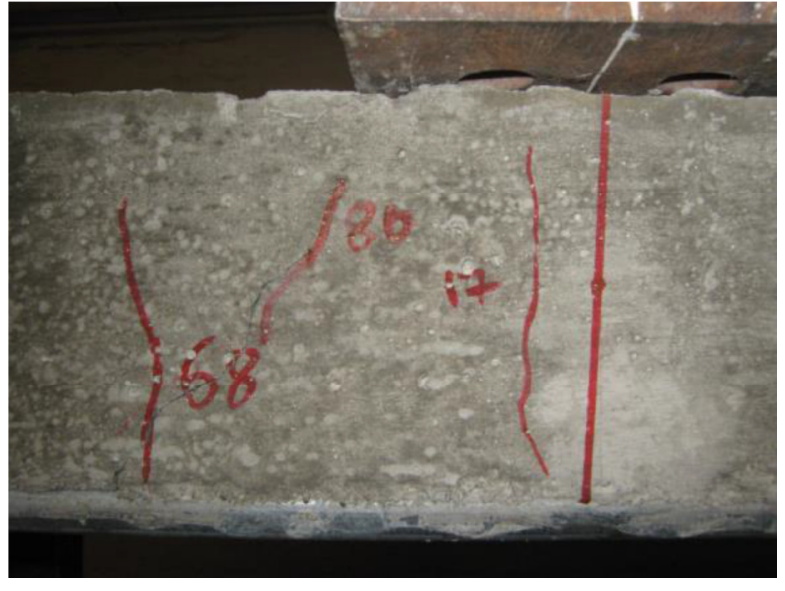

Diagonal Shear cracks - Left hand side

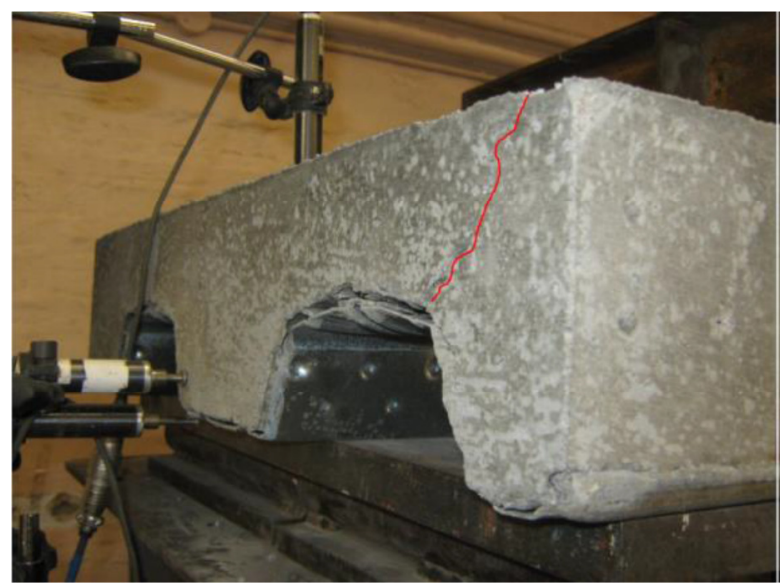

End Slip - Left hand side

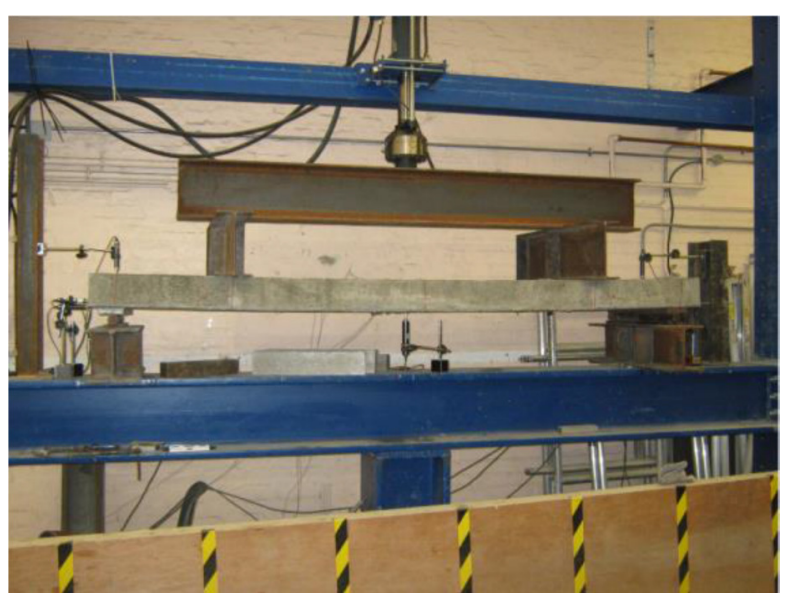

Deformed Specimen

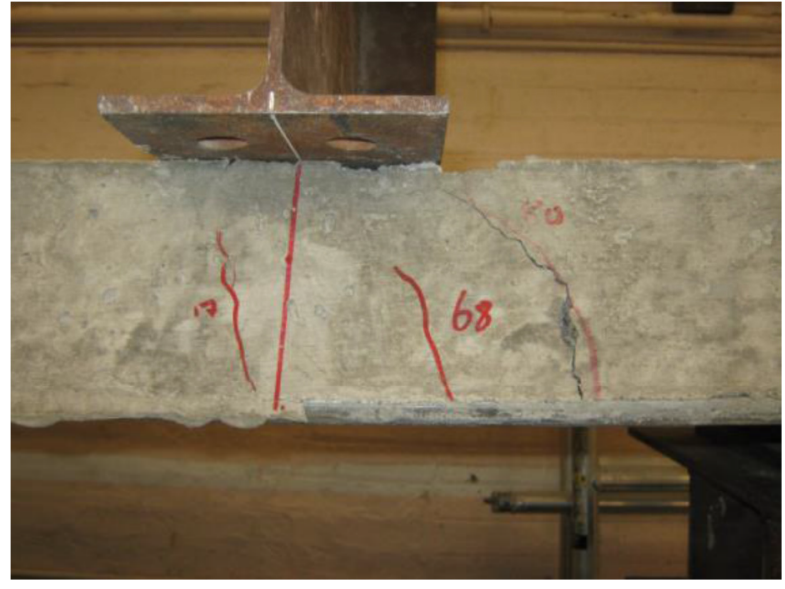

Diagonal Shear cracks - Right hand side

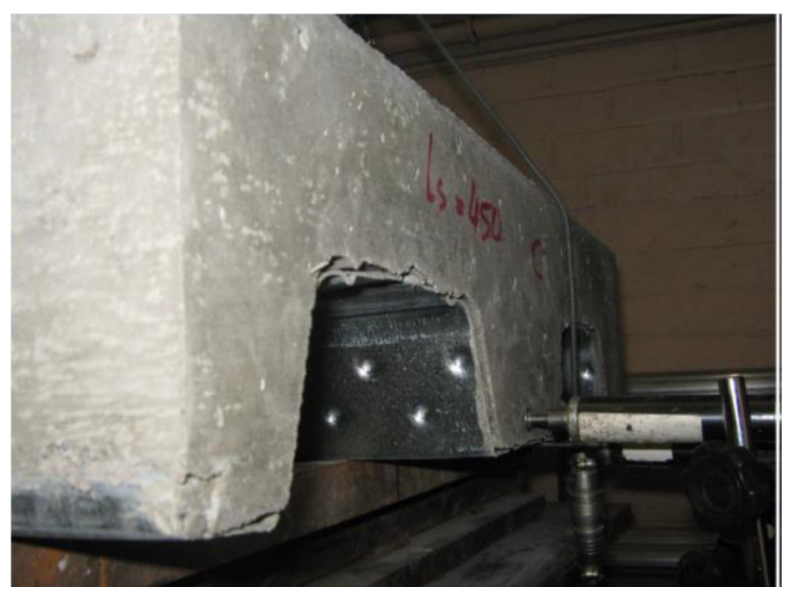

End Slip - Right hand side 


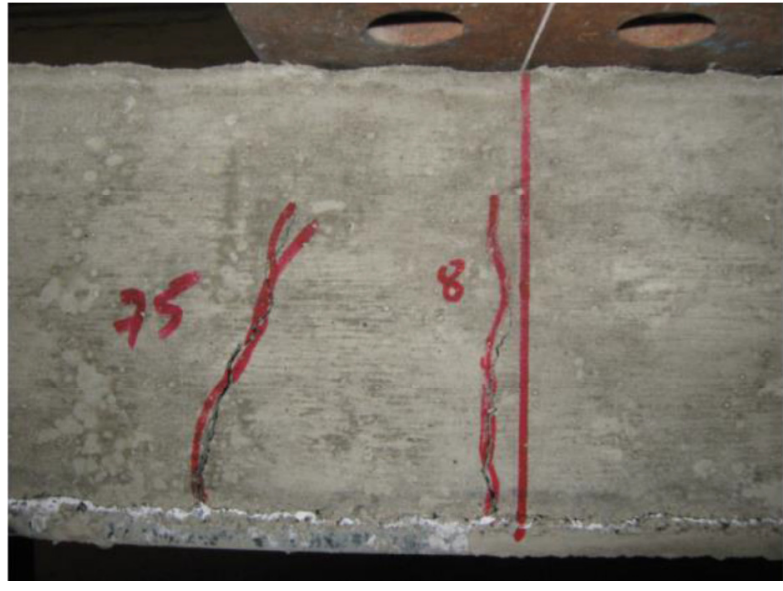

Diagonal Shear cracks - Left hand side

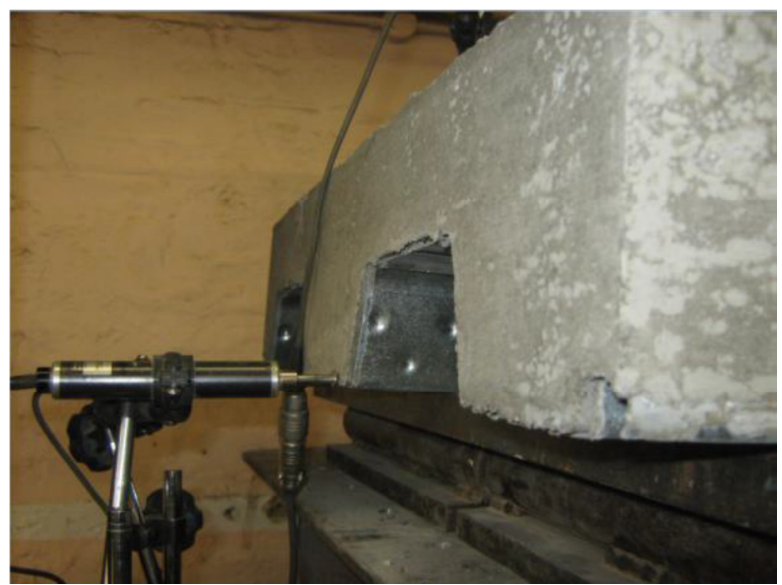

End Slip - Left hand side

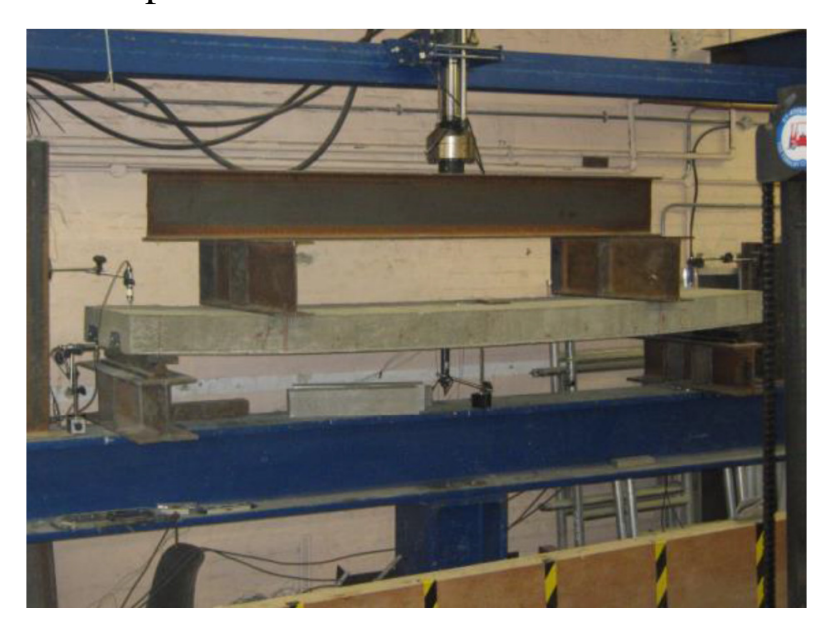

Deformed Specimen

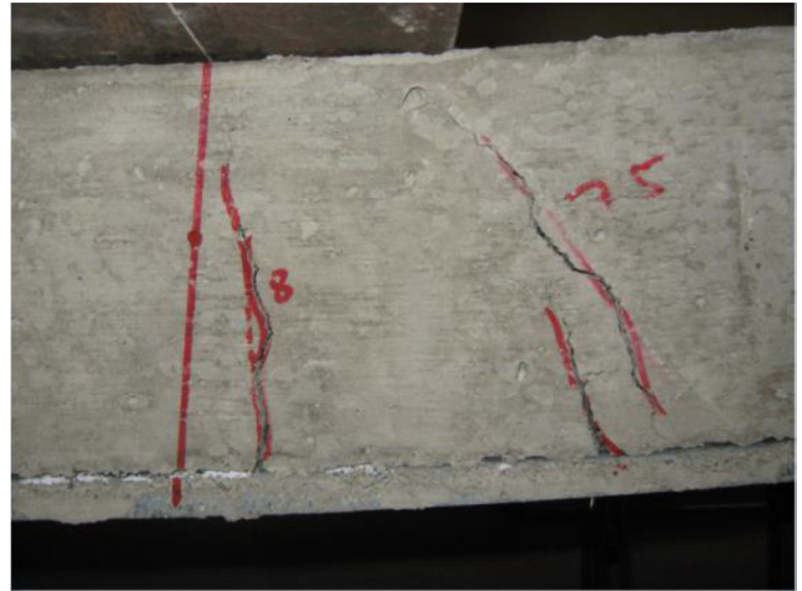

Diagonal Shear cracks - Right hand side

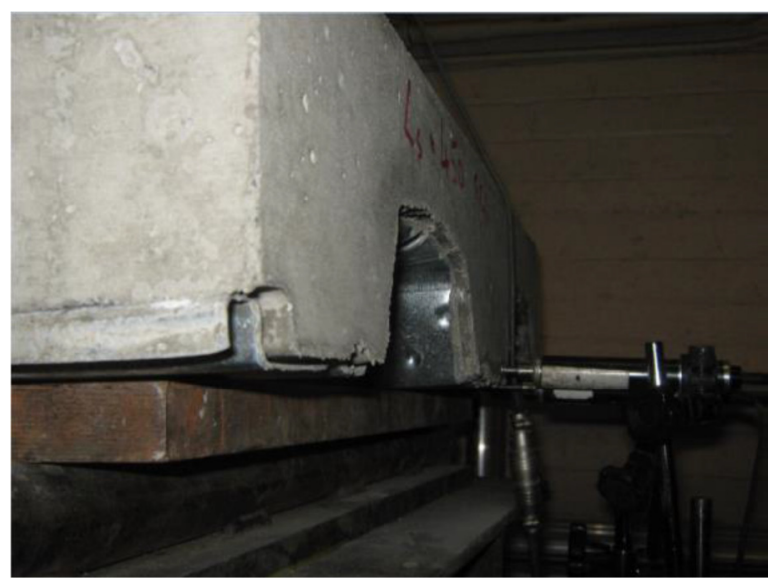

End Slip - Right hand side

End Slip - Right hand side 


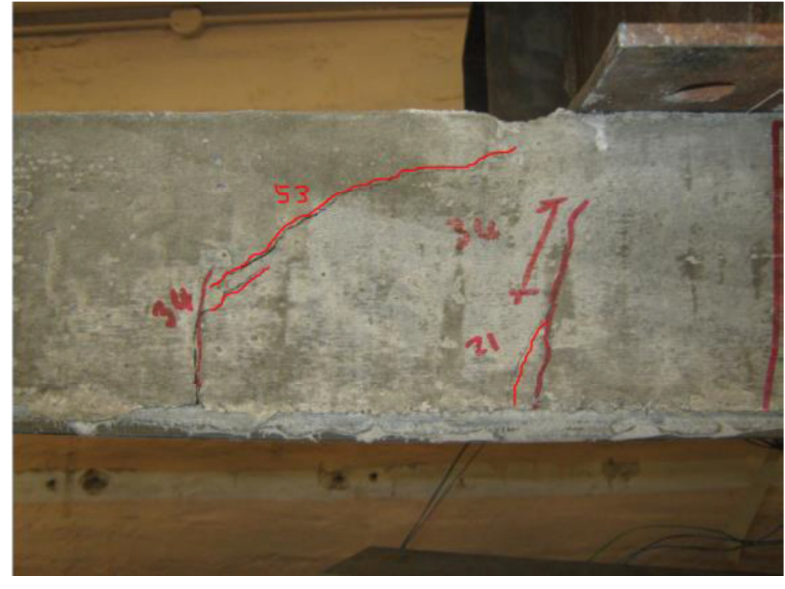

Diagonal Shear cracks - Left hand side

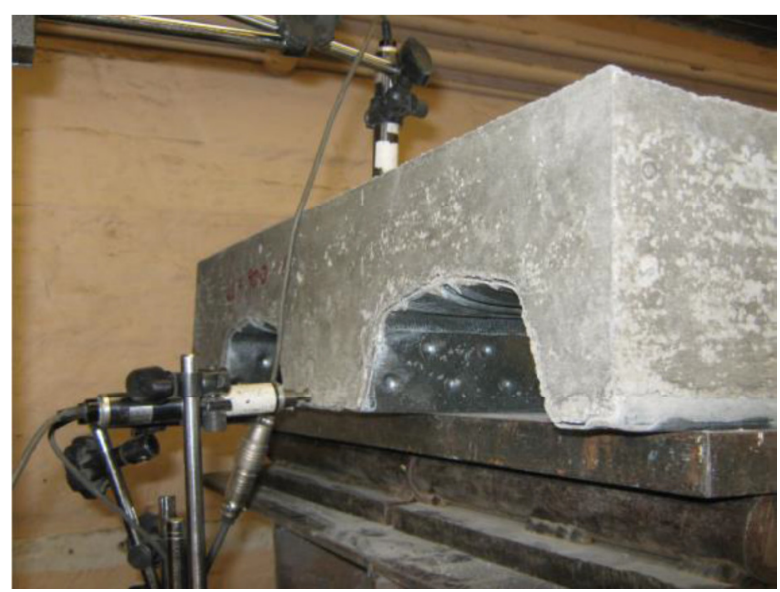

End Slip - Left hand side

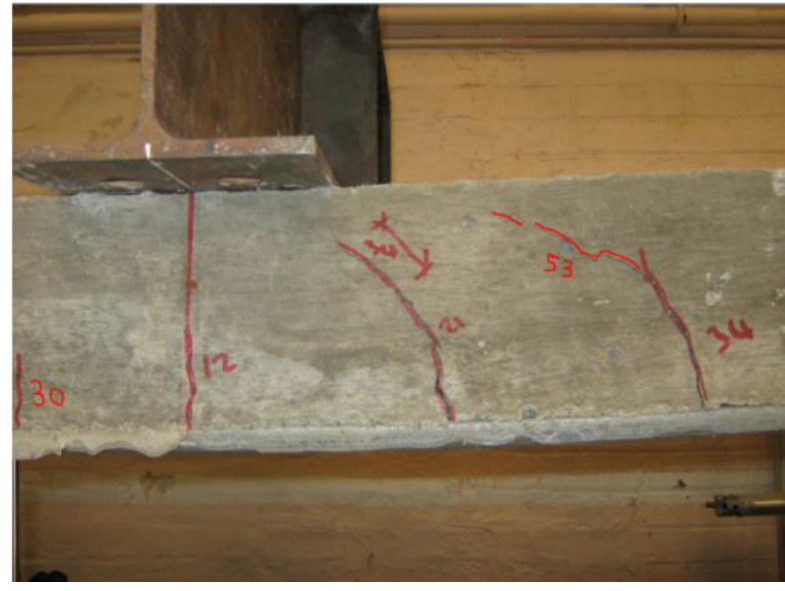

Diagonal Shear cracks - Right hand side

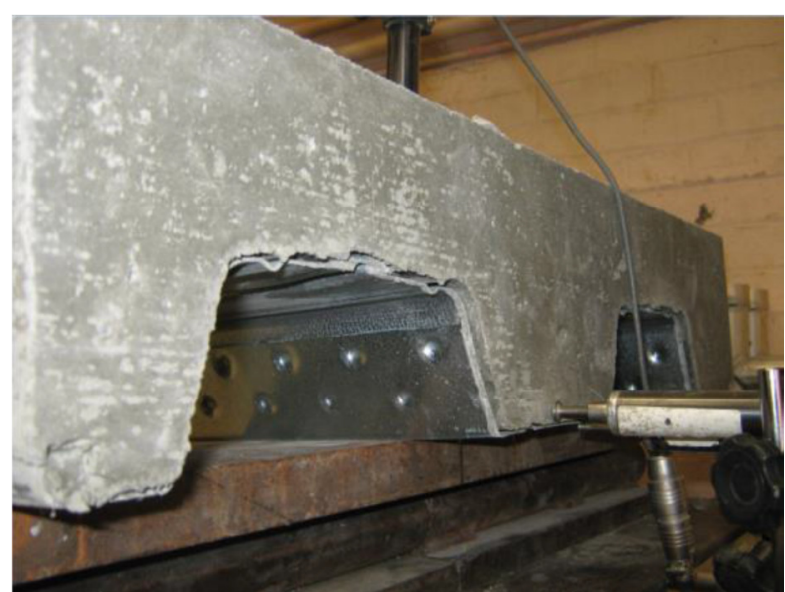

End Slip - Right hand side

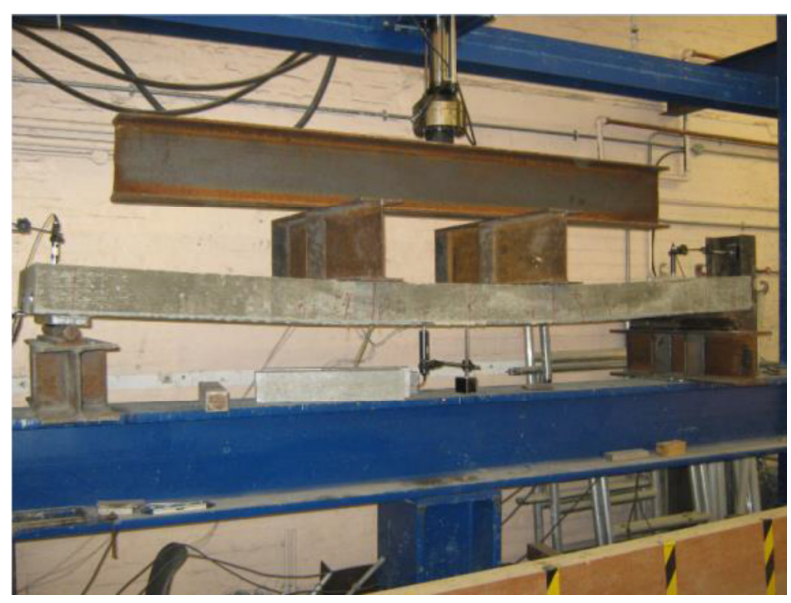

Deformed Specimen

Figure 20 Diagonal cracking, end slip and specimen deformation for the Control slab with the $900 \mathrm{~mm}$ shear length 


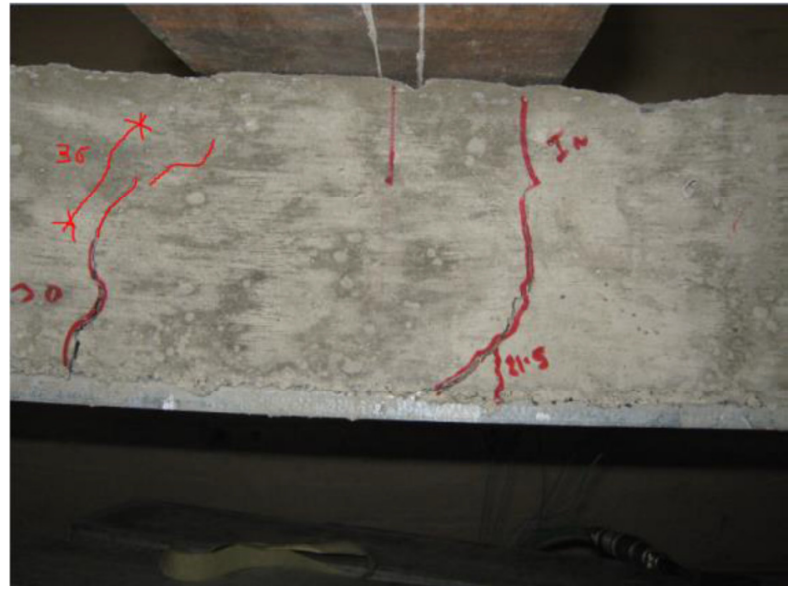

Diagonal Shear cracks - Left hand side

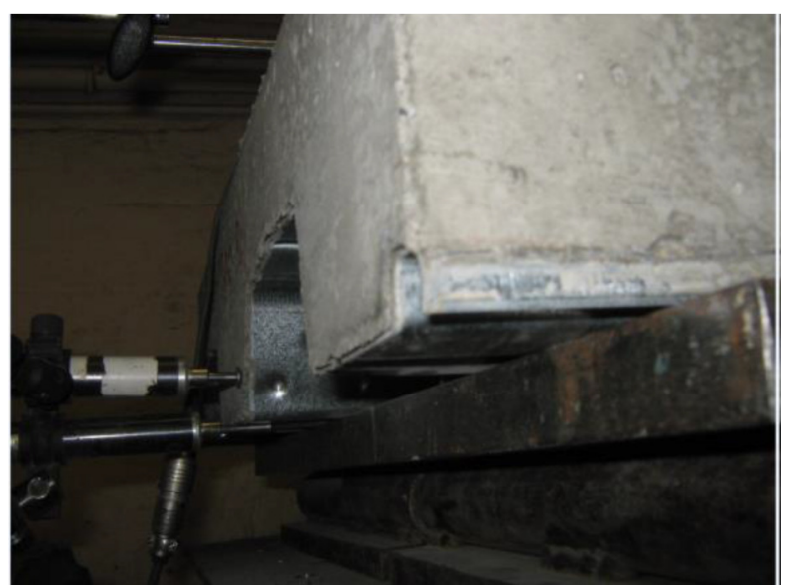

End Slip - Left hand side

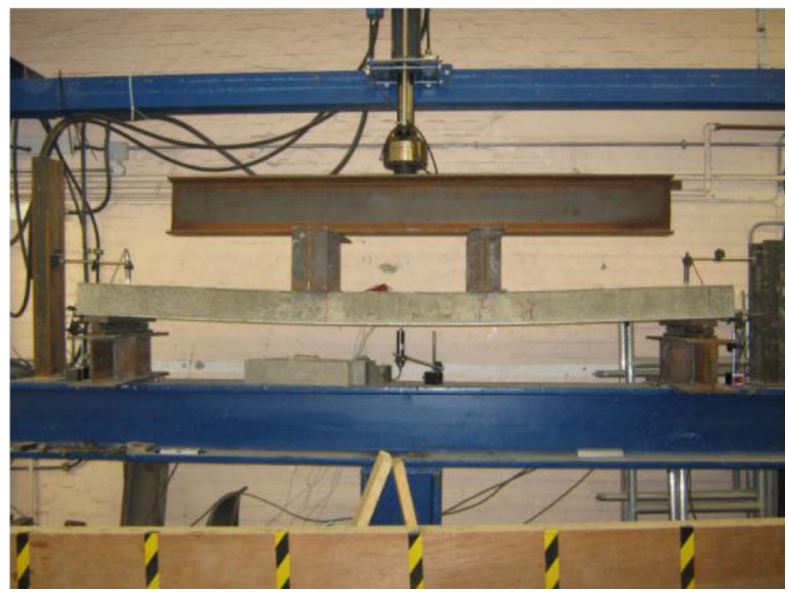

Deformed Specimen

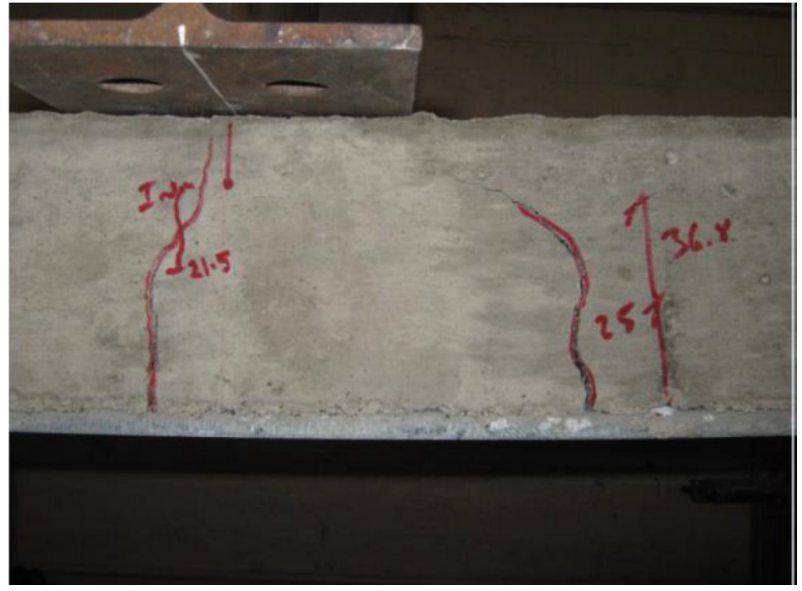

Diagonal Shear cracks - Right hand side

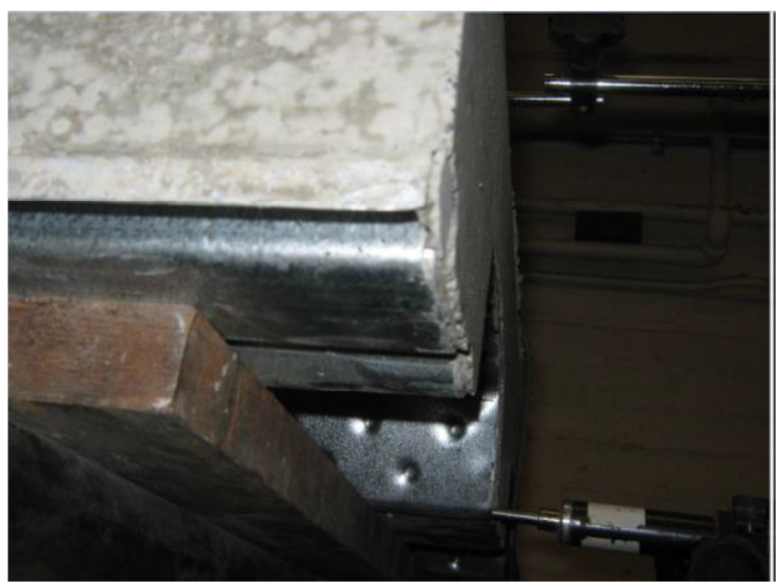

End Slip - Right hand side

Figure 21 Diagonal cracking, end slip and specimen deformation for the CRC slab with a 900mm shear span 


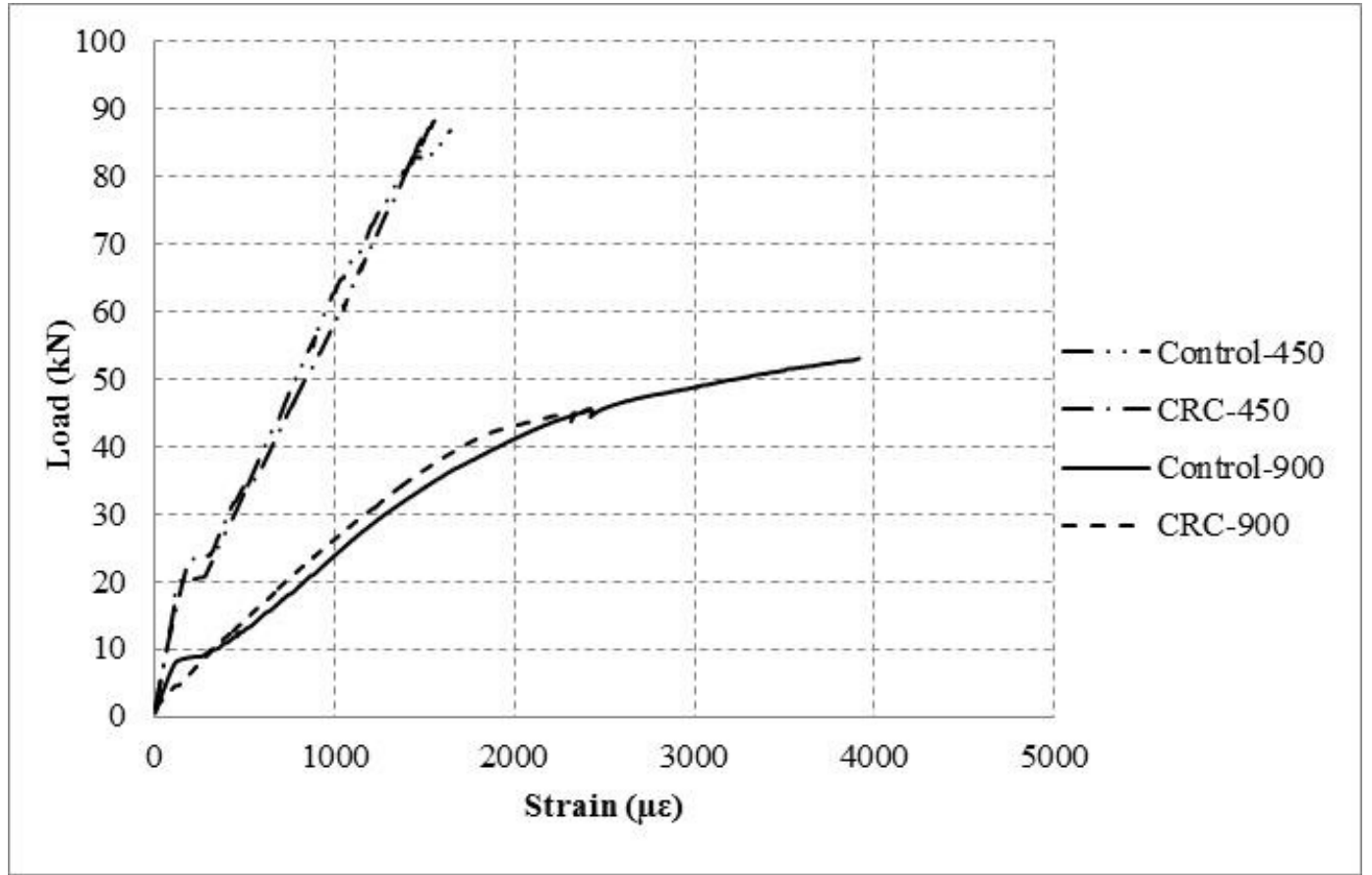

Figure 22 Applied load and bottom strain readings

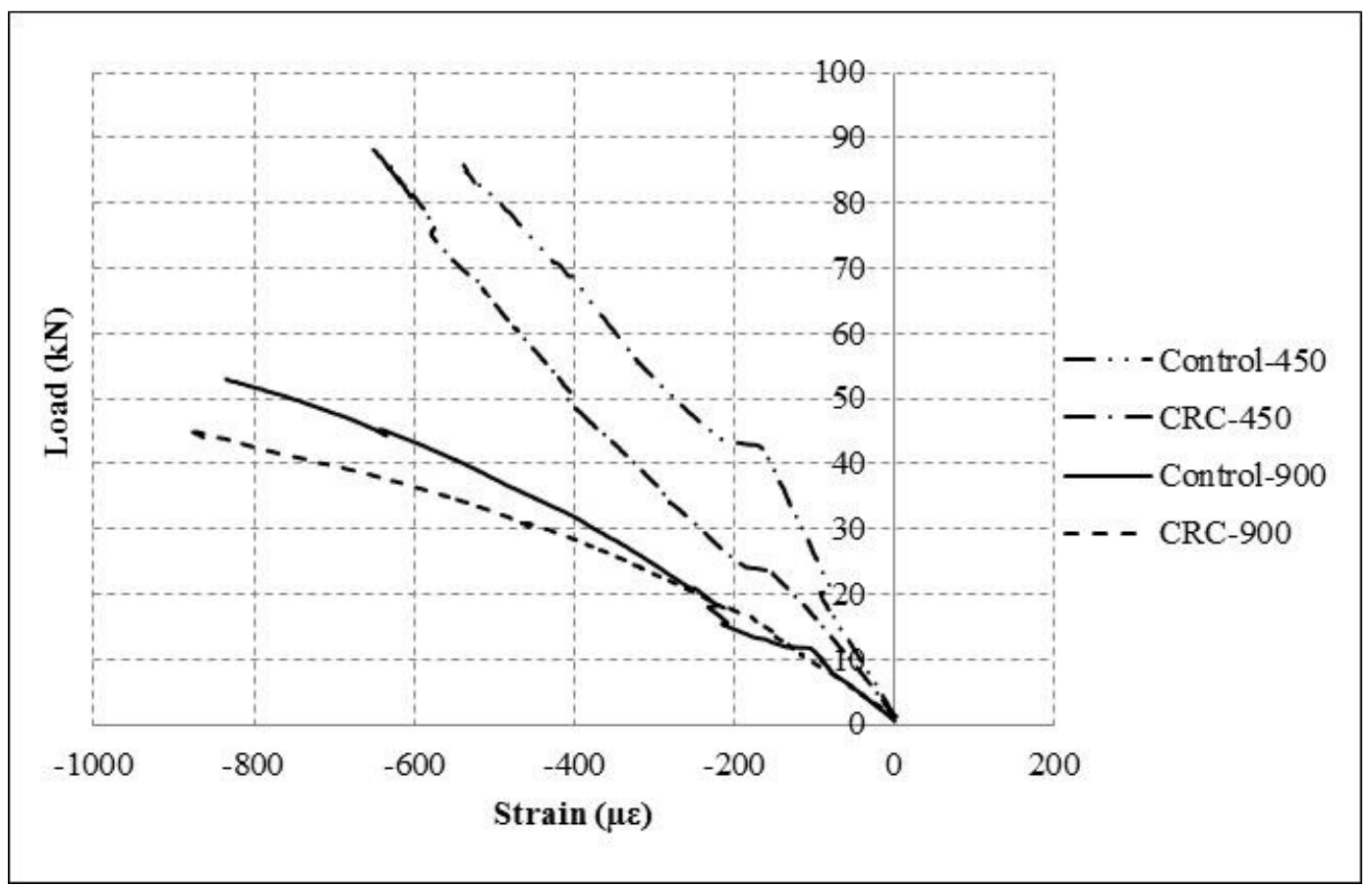

Figure 23 Applied load and top strain readings 


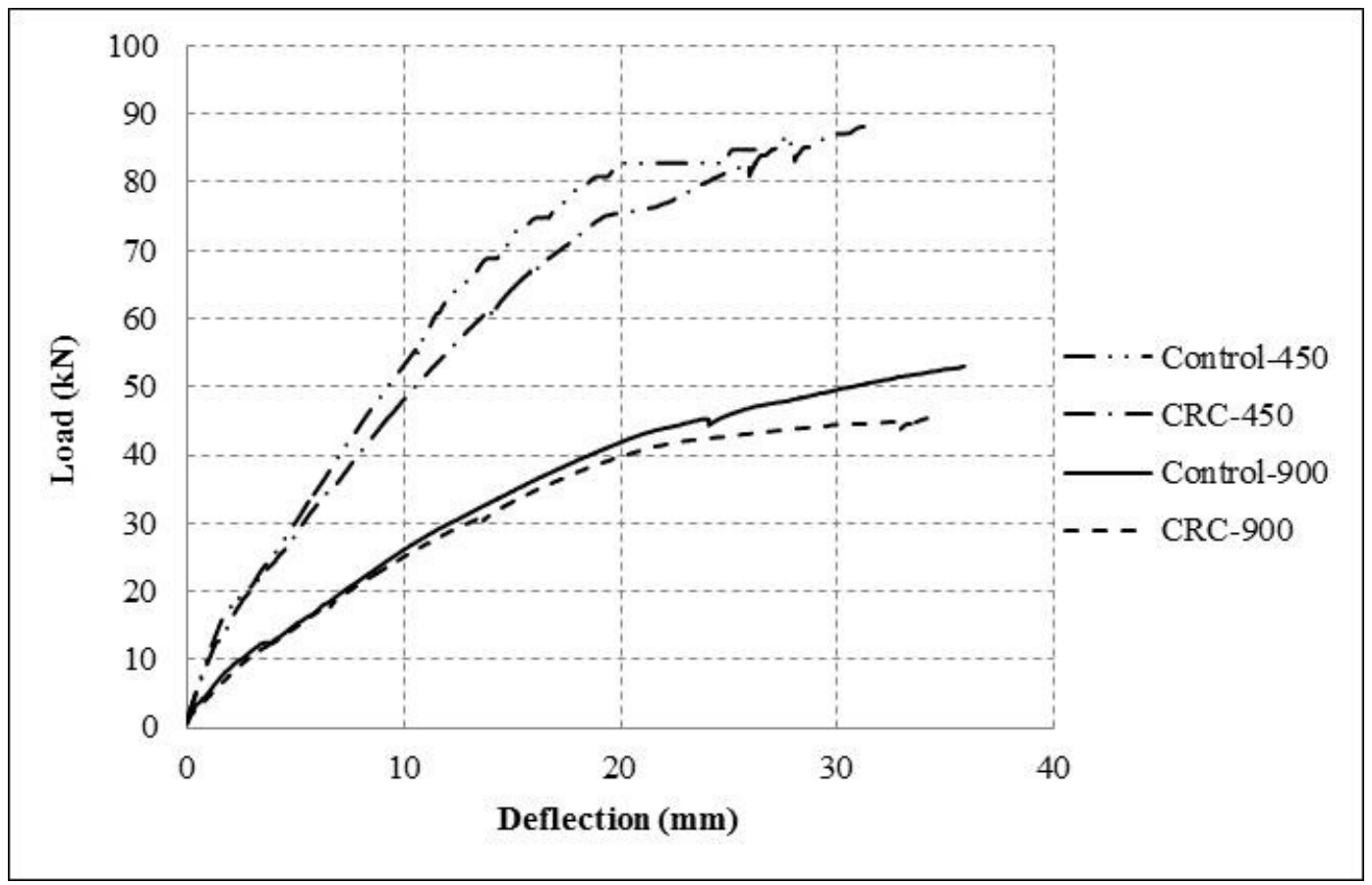

Figure 24 Mid-span deflection readings

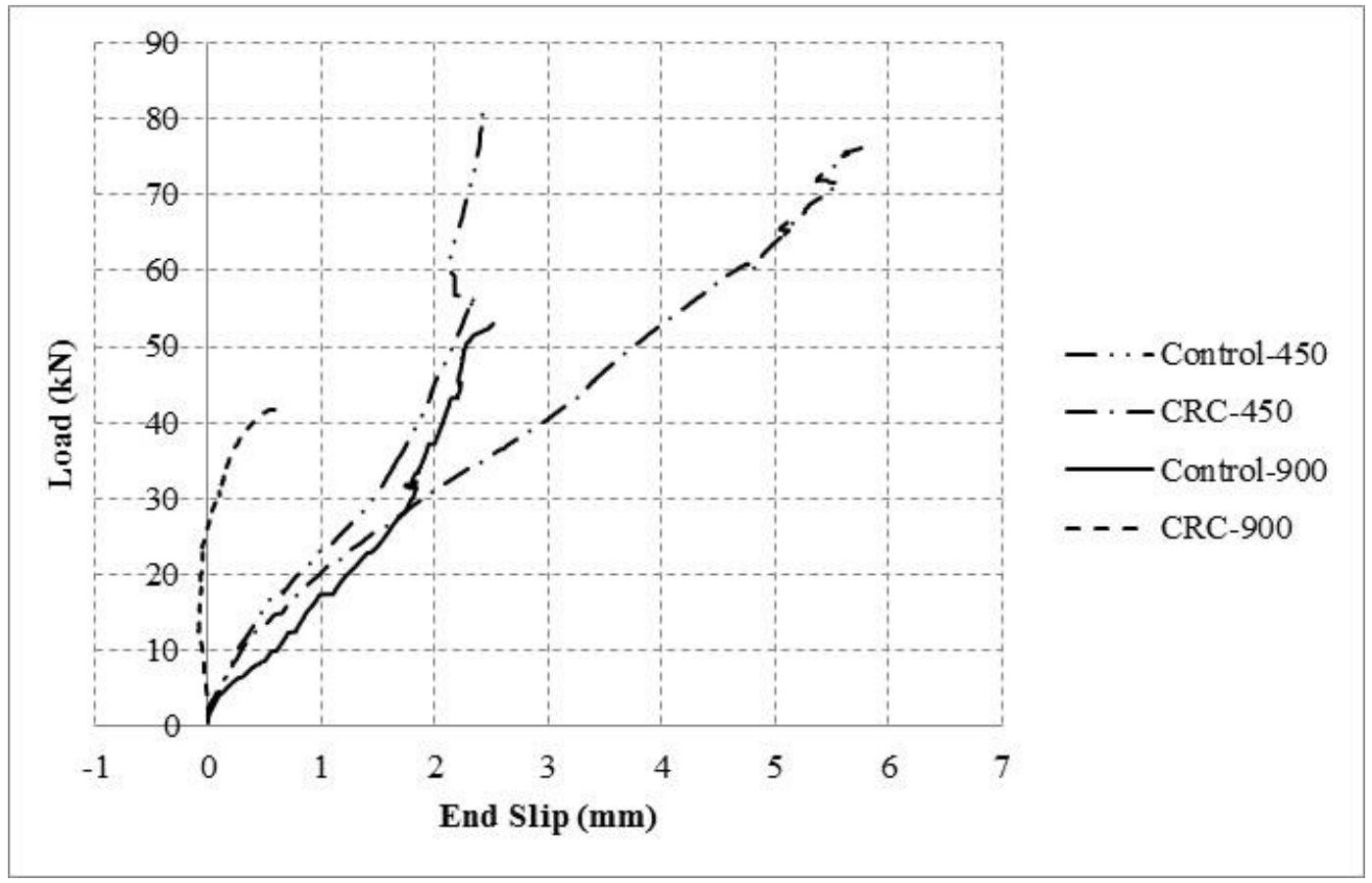

Figure 25 End slippage on left-hand side 


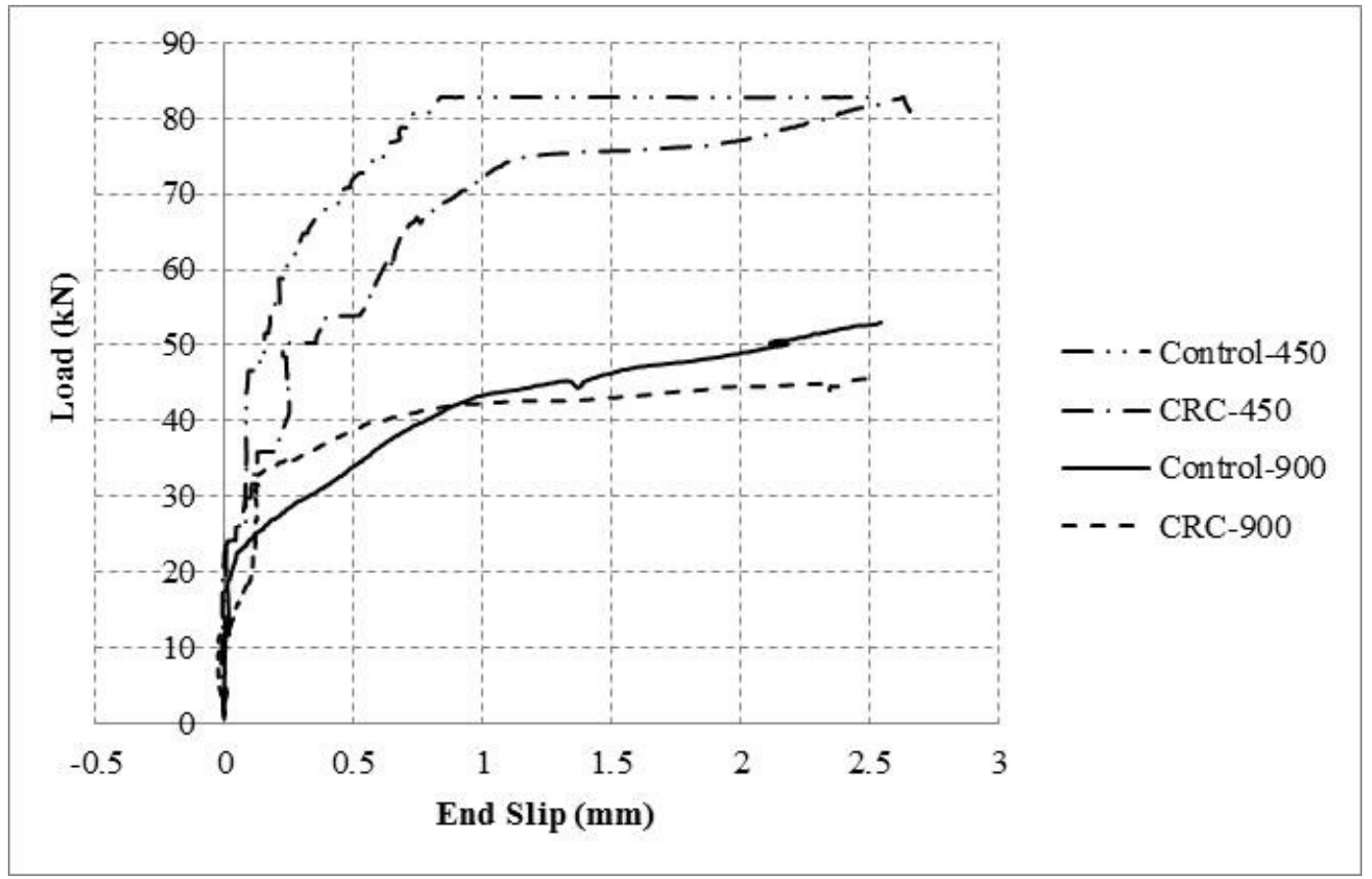

Figure 26 End slippage on right-hand side

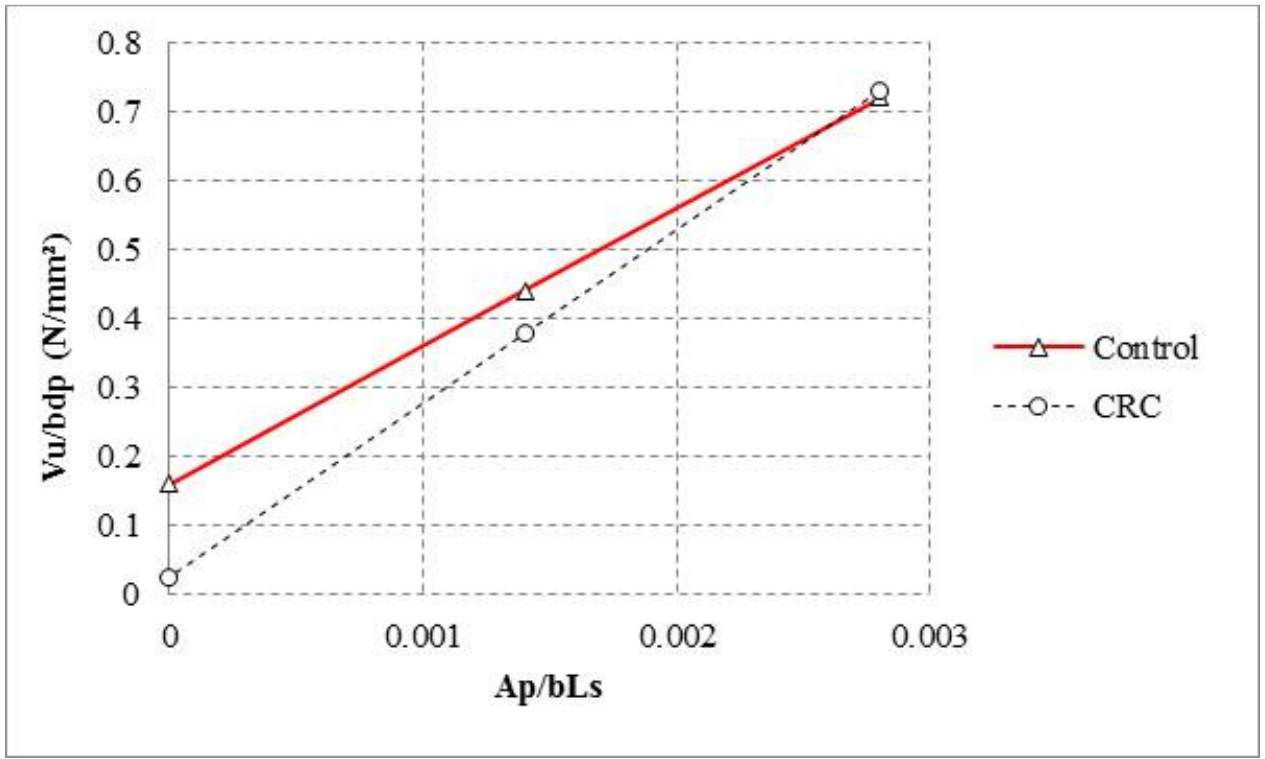

Figure $27 \mathrm{~m}-\mathrm{k}$ points for $\mathrm{CRC}$ and conventional concrete composite slabs 


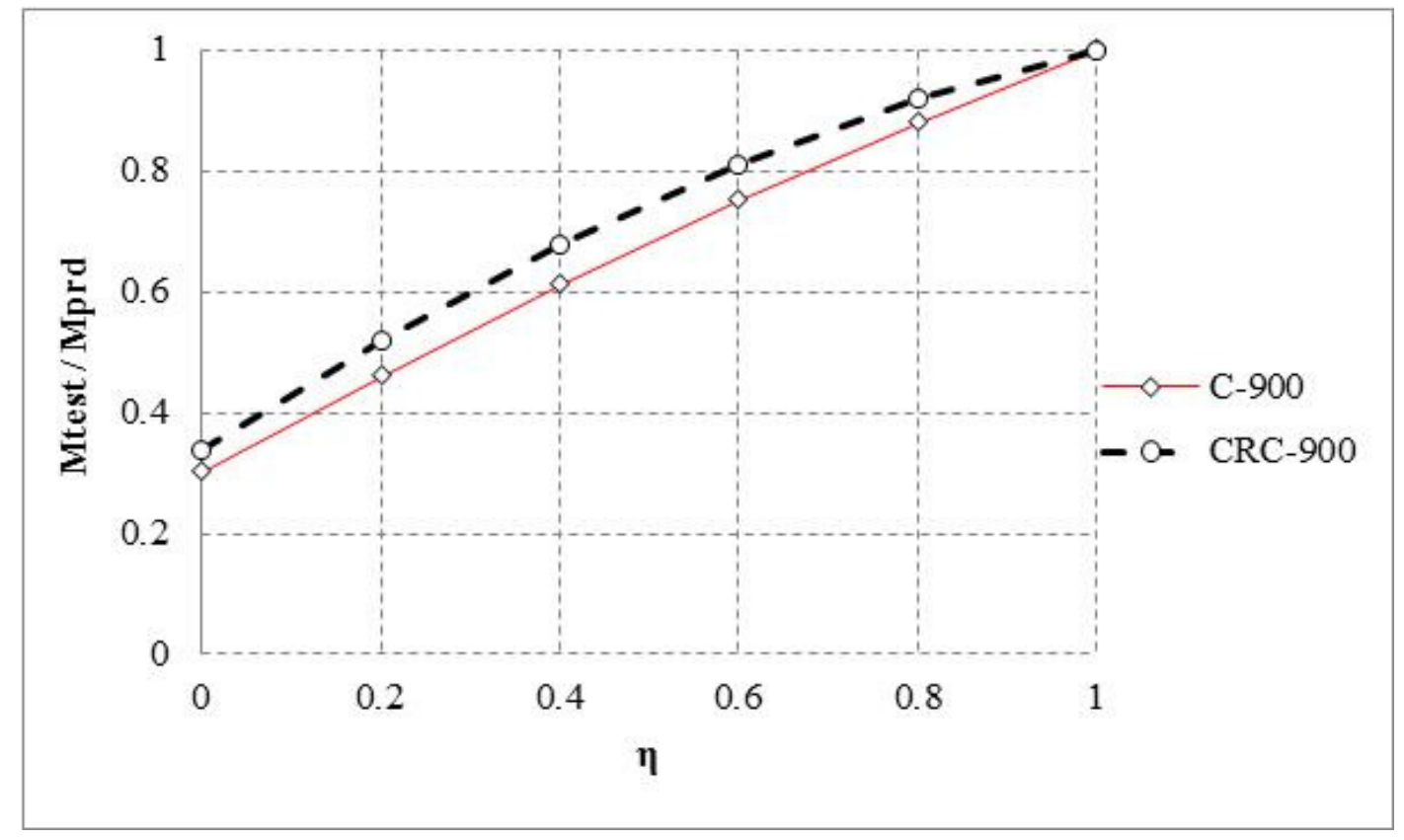

Figure 28 PSC curves for CRC and conventional concrete composite slabs 


\section{LIST OF TABLES}

Table 1 Mix proportions for Control Mix (0\% CRC)

\begin{tabular}{|c|c|c|c|c|}
\hline $\begin{array}{c}\text { Water } \\
\mathrm{kg} / \mathrm{m}^{3}\end{array}$ & $\begin{array}{c}\text { CEM I } \\
\mathrm{kg} / \mathrm{m}^{3}\end{array}$ & $\begin{array}{c}\text { CRC } \\
\mathrm{kg} / \mathrm{m}^{3}\end{array}$ & $\begin{array}{c}\text { FA } \\
\mathrm{kg} / \mathrm{m}^{3}\end{array}$ & $\begin{array}{c}\text { CA } \\
\mathrm{kg} / \mathrm{m}^{3}\end{array}$ \\
\hline 94 & 188 & 0 & 322 & 363 \\
\hline
\end{tabular}

FA - Fine aggregate; CA - Course Aggregate (10mm)

Table 2 Mix proportions for CRC Mix

\begin{tabular}{|c|c|c|c|c|}
\hline $\begin{array}{c}\text { Water } \\
\mathrm{kg} / \mathrm{m}^{3}\end{array}$ & $\begin{array}{c}\text { CEM I } \\
\mathrm{kg} / \mathrm{m}^{3}\end{array}$ & $\begin{array}{c}\text { CRC } \\
\mathrm{kg} / \mathrm{m}^{3}\end{array}$ & $\begin{array}{c}\text { FA } \\
\mathrm{kg} / \mathrm{m}^{3}\end{array}$ & $\begin{array}{c}\text { CA } \\
\mathrm{kg} / \mathrm{m}^{3}\end{array}$ \\
\hline 138 & 276 & 20.5 & 437 & 532 \\
\hline
\end{tabular}

FA - Fine aggregate; CA - Course Aggregate (10mm)

Table $3 \quad$ Profiled steel deck Properties

\begin{tabular}{|l|c|c|}
\hline Property & Symbol & Value \\
\hline Sheet Width $(\mathrm{mm})$ & $b$ & 600 \\
\hline Yield Stress $\left(\mathrm{N} / \mathrm{mm}^{2}\right)$ & $f_{y p}$ & 350 \\
\hline Slab Depth $(\mathrm{mm})$ & $h_{t}$ & 130 \\
\hline Slab Length $(\mathrm{mm})$ & $L$ & 2700 \\
\hline Nominal Thickness $(\mathrm{mm})$ & $d_{d}$ & 0.9 \\
\hline Design Thickness $(\mathrm{mm})$ & & 0.86 \\
\hline Profile Weight $\left(\mathrm{kN} / \mathrm{m}^{2}\right)$ & & 0.103 \\
\hline Area of Steel $\left(\mathrm{mm}^{2} / \mathrm{m}\right)$ & $A_{s}$ & 1276 \\
\hline Height to NA & $e$ & 29.6 \\
\hline I (cm $\left.{ }^{4} / \mathrm{m}\right)$ & $I$ & 92.77 \\
\hline Sagging moment capacity $(\mathrm{kNm} / \mathrm{m})$ & & 9.3 \\
\hline Hogging moment capacity $(\mathrm{kNm} / \mathrm{m})$ & & 7.5 \\
\hline
\end{tabular}


Table $4 \quad$ Weight and density of concrete

\begin{tabular}{|c|c|c|}
\hline Concrete & Average cube weight $\mathbf{( k g )}$ & Average cube density $\left(\mathbf{k g} / \mathbf{m}^{\mathbf{3}}\right)$ \\
\hline Control & 7.915 & 2,345 \\
\hline CRC & 7.759 & 2,299 \\
\hline
\end{tabular}

Table $5 \quad$ Failure mechanism during loading

\begin{tabular}{|c|c|c|}
\hline $\begin{array}{c}\text { Slab } \\
\text { reference }\end{array}$ & $\begin{array}{c}\text { Failure } \\
\text { load } \\
(\mathbf{k N})\end{array}$ & Failure mechanism \\
\hline $\mathrm{C}-450$ & 86.75 & $\begin{array}{l}\text { 17kN - Cracking and popping sounds indicating the loss of } \\
\text { chemical bond between the concrete and steel deck interface. } \\
\text { Vertical hairline cracks visible under loads at the crack inducers } \\
30 \mathrm{kN} \text { - Slippage occurs along the constant shear zone } \\
68-80 \mathrm{kN} \text { - } 1 \mathrm{~mm} \text { wide diagonal shear cracks appear at the bottom } \\
\text { of the constant shear zones and extend diagonally upwards to the } \\
\text { point of loading until failure at } 86.75 \mathrm{kN} \text { occurred. } \\
86.75 \mathrm{kN} \text { - Failure with mid-span deflection of } 28 \mathrm{~mm} \text {. }\end{array}$ \\
\hline CRC-450 & 88.16 & $\begin{array}{l}8 \mathrm{kN} \text { - Vertical hairline cracks visible under the loading points } \\
\text { where the crack inducers are positioned. } \\
@ 12.2 \mathrm{kN} \text { - Slippage is observed along the constant shear zone } \\
20 \mathrm{kN} \text { - A loud popping sound heard suggesting the chemical bond } \\
\text { between the concrete and steel is lost } \\
60 \mathrm{kN} \text { - Diagonal shear cracks forming on both sides of the } \\
\text { constant shear zone } \\
75 \mathrm{kN} \text { - Shear cracks have widened and diagonally extended the } \\
\text { full depth of the concrete slab. } \\
88.16 \mathrm{kN} \text { - Failure with mid-span deflection of } 31.5 \mathrm{~mm}\end{array}$ \\
\hline C-900 & 53.02 & $\begin{array}{l}9 \mathrm{kN} \text { - Cracking/popping sounds indicating a loss in chemical bond } \\
\text { between the concrete and the profiled steel deck interface. } \\
12 \mathrm{kN} \text { - Vertical hairline crack visible at the load point at the crack } \\
\text { inducer position } \\
21 \mathrm{kN} \text { - Diagonal hairline shear cracks form from the bottom of the } \\
\text { concrete on both sides of the constant shear zones } \\
34 \mathrm{kN} \text { - Vertical flexural and diagonal shear cracks continue } \\
53.02 \mathrm{kN} \text { - Failure with a mid-span deflection of } 38.86 \mathrm{~mm}\end{array}$ \\
\hline CRC-900 & 49.59 & $\begin{array}{l}11.3 \mathrm{kN} \text { - Cracking/popping sounds heard. } \\
25 \mathrm{kN} \text { - Diagonal hairline crack forming } 140 \mathrm{~mm} \text { from the load } \\
30 \mathrm{kN} \text { - A diagonal hairline crack forming } 115 \mathrm{~mm} \text { from the load } \\
36.8 \mathrm{kN} \text { - Diagonal shears cracks, forming from the bottom of the } \\
\text { concrete slab, continue to extend diagonally upwards } \\
44 \mathrm{kN} \text { - Very noticeable separation between concrete and steel } \\
49.59 \mathrm{kN} \text { - Failure with a mid-span deflection of } 34.65 \mathrm{~mm} \text {. }\end{array}$ \\
\hline
\end{tabular}


Table $6 \quad$ Maximum experimental shear forces $\left(V_{u}\right)$

\begin{tabular}{|c|c|c|}
\hline Concrete & $\begin{array}{c}\text { Failure Load } \\
\left(\mathbf{W}_{\mathbf{u}}, \mathbf{k N}\right)\end{array}$ & $\begin{array}{c}\text { Experimental shear force } \\
\left(\mathbf{V}_{\mathbf{u}}, \mathbf{=} \mathbf{W}_{\mathbf{u}} / \mathbf{2}, \mathbf{k N}\right)\end{array}$ \\
\hline C-450 & 86.75 & 43.38 \\
\hline C-900 & 53.02 & 26.51 \\
\hline CRC-450 & 88.16 & 30.28 \\
\hline CRC-900 & 45.59 & 22.8 \\
\hline
\end{tabular}

Table $7 \quad$ m-k method calculations

\begin{tabular}{|c|c|c|c|c|c|c|c|c|}
\hline Concrete & $\boldsymbol{b}(\mathbf{m m})$ & $d_{p}(\mathbf{m m})$ & $\begin{array}{c}f_{c m} \\
\left(\mathbf{N} / \mathbf{m m}^{2}\right)\end{array}$ & $\begin{array}{c}\boldsymbol{L}_{\boldsymbol{s}} \\
(\mathbf{m m})\end{array}$ & $\begin{array}{c}A_{p} \\
\left(\mathbf{m m}^{2}\right)\end{array}$ & $\begin{array}{c}\boldsymbol{V}_{u} \\
(\boldsymbol{k N})\end{array}$ & $\begin{array}{c}\boldsymbol{V}_{u} / \mathbf{b} d_{p} \\
\left(\mathbf{N} / \mathbf{m m}^{2}\right)\end{array}$ & $A_{p} / b_{L_{s}}$ \\
\hline C-450 & 600 & 100.4 & 35.75 & 450 & 765.6 & 43.37 & 0.72 & 0.0028 \\
\hline C-900 & 600 & 100.4 & 35.75 & 900 & 765.6 & 26.51 & 0.44 & 0.0014 \\
\hline CRC-450 & 600 & 100.4 & 18.62 & 450 & 765.6 & 44.08 & 0.73 & 0.0028 \\
\hline CRC-900 & 600 & 100.4 & 18.62 & 900 & 765.6 & 22.79 & 0.38 & 0.0014 \\
\hline
\end{tabular}

Table $8 \quad$ PSC Method calculation - Control Concrete

\begin{tabular}{|c|c|c|c|c|c|}
\hline $\begin{array}{c}\eta \\
\left(=N_{c} / N_{c f}\right)\end{array}$ & $\begin{array}{c}N_{c}(=\eta \\
\left.* N_{c f}\right) \\
(k N)\end{array}$ & $\begin{array}{c}M_{p r} \\
\left(1.25 M_{p a}\left(1-N_{c} / N_{c f}\right)\right. \\
(k N m)\end{array}$ & $\begin{array}{c}z \\
\left(h_{\tau}-0.5 \eta x_{p l}-e\right) \\
(m m)\end{array}$ & $\begin{array}{c}M_{r m} \\
\left(N_{c} *_{z}+M_{p r}\right) \\
(k N m)\end{array}$ & $\begin{array}{l}M_{\text {test }} \\
M_{\text {prd }}\end{array}$ \\
\hline 0 & 0.00 & 11.625 & 100.40 & 11.625 & 0.30 \\
\hline 0.2 & 89.32 & 9.30 & 97.95 & 18.05 & 0.46 \\
\hline 0.4 & 178.64 & 6.975 & 95.50 & 24.04 & 0.61 \\
\hline 0.6 & 267.96 & 4.65 & 93.05 & 29.58 & 0.75 \\
\hline 0.8 & 357.28 & 2.325 & 90.60 & 34.70 & 0.88 \\
\hline 1.0 & 446.6 & 0.000 & 88.15 & 36.37 & 1.00 \\
\hline
\end{tabular}

Where $\mathrm{M}_{\mathrm{pa}}=9.3 \mathrm{kNm} / \mathrm{m}$ (Table 3), $\mathrm{M}_{\mathrm{p}, \mathrm{Rd}}=\mathrm{N}_{\mathrm{cf}} *\left(\mathrm{~d}_{\mathrm{p}}-0.5 \mathrm{x}\right)=446,660 *(100.4-0.5 * 24.49)=$ $39.37 \mathrm{kNm} / \mathrm{m}, \mathrm{N}_{\mathrm{cf}}=\mathrm{A}_{\mathrm{p}} * \mathrm{f}_{\mathrm{yp}}=1276 * 350=446.6 \mathrm{kN} / \mathrm{m}, \mathrm{h}_{\mathrm{t}}=130 \mathrm{~mm}\left(\right.$ Table 3), $\mathrm{x}_{\mathrm{pl}}=$ $\mathrm{N}_{\mathrm{cf}} /\left(\mathrm{b} * 0.85 \mathrm{f}_{\mathrm{ck}}\right)=446,600 /(600 * 0.85 * 35.75)=24.49 \mathrm{~mm}, \mathrm{e}=29.6 \mathrm{~mm}($ Table 3$)$. 
Table 9 PSC Method calculation - CRC Slabs

\begin{tabular}{|c|c|c|c|c|c|}
\hline $\begin{array}{c}\eta \\
\left(=N_{c} / N_{c f}\right)\end{array}$ & $\begin{array}{c}N_{c}(=\eta \\
\left.* N_{c f}\right) \\
(k N)\end{array}$ & $\begin{array}{c}M_{p r} \\
\left(1.25 M_{p a}\left(1-N_{c} / N_{c f}\right)\right. \\
(k N m)\end{array}$ & $\begin{array}{c}z \\
\left(h_{\tau}-0.5 \eta x_{p l}-e\right) \\
(m m)\end{array}$ & $\begin{array}{c}M_{r m} \\
\left(N_{c} *_{\left.z+M_{p r}\right)}\right. \\
(k N m)\end{array}$ & $\begin{array}{c}M_{\text {test }} \\
M_{\text {prd }}\end{array}$ \\
\hline 0 & 0.00 & 11.625 & 100.40 & 11.625 & 0.34 \\
\hline 0.2 & 89.32 & 9.30 & 95.70 & 18.85 & 0.52 \\
\hline 0.4 & 178.64 & 6.975 & 90.99 & 23.23 & 0.68 \\
\hline 0.6 & 267.96 & 4.65 & 86.29 & 27.77 & 0.81 \\
\hline 0.8 & 357.28 & 2.325 & 81.59 & 31.48 & 0.92 \\
\hline 1.0 & 446.6 & 0.000 & 76.89 & 34.34 & 1.00 \\
\hline
\end{tabular}

Where $\mathrm{M}_{\mathrm{pa}}=9.3 \mathrm{kNm} / \mathrm{m}$ (Table 3), $\mathrm{M}_{\mathrm{p}, \mathrm{Rd}}=\mathrm{N}_{\mathrm{cf}}\left(\mathrm{d}_{\mathrm{p}}-0.5 \mathrm{x}\right)=446,660 *(100.4-0.5 * 24.49)=$ $34.34 \mathrm{kNm} / \mathrm{m}, \mathrm{N}_{\mathrm{cf}}=\mathrm{A}_{\mathrm{p}} * \mathrm{f}_{\mathrm{yp}}=1276 * 350=446.6 \mathrm{kN} / \mathrm{m}, \mathrm{h}_{\mathrm{t}}=130 \mathrm{~mm}\left(\right.$ Table 3), $\mathrm{x}_{\mathrm{pl}}=$ $\mathrm{N}_{\mathrm{cf}} /\left(\mathrm{b} * 0.85 \mathrm{f}_{\mathrm{ck}}\right)=446,600 /(600 * 0.85 * 18.62)=47.03 \mathrm{~mm}, \mathrm{e}=29.6 \mathrm{~mm}($ Table 3$)$. 